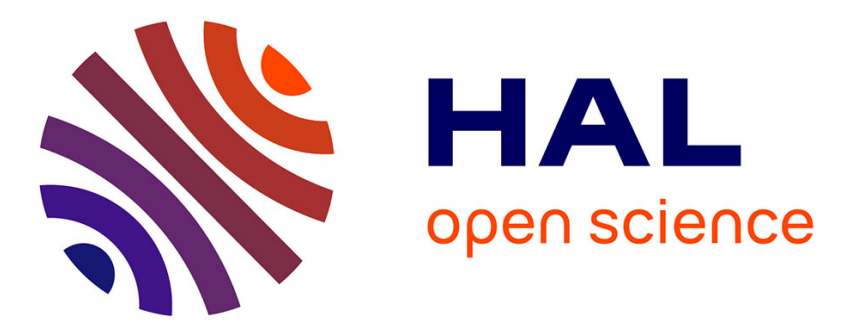

\title{
Identification of a Novel 1,4,8-Triazaphenanthrene Derivative as a Neuroprotectant for Dopamine Neurons Vulnerable in Parkinson's Disease
}

Gael Le Douaron, Laurent Ferrié, Julia E. Sepulveda-Diaz, Blandine Séon-Méniel, Rita Raisman-Vozari, Patrick Pierre Michel, Bruno Figadère

\section{To cite this version:}

Gael Le Douaron, Laurent Ferrié, Julia E. Sepulveda-Diaz, Blandine Séon-Méniel, Rita RaismanVozari, et al.. Identification of a Novel 1,4,8-Triazaphenanthrene Derivative as a Neuroprotectant for Dopamine Neurons Vulnerable in Parkinson's Disease. ACS Chemical Neuroscience, 2017, 10.1021/acschemneuro.6b00385 . hal-01480347

\section{HAL Id: hal-01480347 \\ https: / hal.sorbonne-universite.fr/hal-01480347}

Submitted on 1 Mar 2017

HAL is a multi-disciplinary open access archive for the deposit and dissemination of scientific research documents, whether they are published or not. The documents may come from teaching and research institutions in France or abroad, or from public or private research centers.
L'archive ouverte pluridisciplinaire HAL, est destinée au dépôt et à la diffusion de documents scientifiques de niveau recherche, publiés ou non, émanant des établissements d'enseignement et de recherche français ou étrangers, des laboratoires publics ou privés. 


\title{
Identification of a Novel 1,4,8-Triazaphenanthrene Derivative as a Neuroprotectant for Dopamine Neurons Vulnerable in Parkinson's Disease
}

Gael Le Douaronłł, Laurent Ferriét, Julia E. Sepulveda-Diazł, Blandine Séon-Méniel†, Rita Raisman-Vozarił, Patrick P. Michel ${ }^{*}$, Bruno Figadère* ${ }_{\dagger}+$

\section{KEYWORDS}

Suzuki coupling reaction, primary neuronal cultures, neurodegenerative diseases, phenotypic screening, medicinal chemistry.

\begin{abstract}
Parkinson's disease (PD) is a chronic degenerative disorder characterized by typical motor symptoms caused by the death of dopamine (DA) neurons in the midbrain and ensuing shortage of DA in the striatum, at the level of nerve terminals. No curative treatment is presently available for PD in clinical practice. In our search for neuroprotectants in PD, we generated new 1,4,8-triazaphenanthrenes by combining 6-endo-dig-cycloisomerisation of propargylquinoxalines and Suzuki or Sonogashira cross-coupling reactions. Neuroprotection assessment of newly synthesized 1,4,8-triazaphenanthrenes in a PD cellular model resulted in the discovery of a new hit compound PPQ (5m). Neuroprotection by $\mathbf{5 m}$ was concentrationdependent and the result of a combined effect on intracellular calcium release channels and astroglial cells. Of interest, $\mathbf{5 m}$ also counteracted DA cell loss in a mouse model of PD, making this molecule a promising candidate for PD treatment.
\end{abstract}




\section{INTRODUCTION}

Parkinson's disease (PD) is a chronic neurodegenerative disorder of aging, which is frequent and characterized by a diminished ability for voluntary movements. ${ }^{1}$ Motor symptoms are caused by the progressive disappearance of substantia nigra (SN) dopamine (DA) neurons and the ensuing reduction of DA levels in the striatum, the projection area of these neurons. ${ }^{1}$ The nature of the molecular mechanisms causing disease onset and progression is not yet fully understood, but a number of hypotheses, which are not mutually exclusive, currently prevail. Most notably, deficits in mitochondrial function, disturbances in protein or calcium homeostasis, oxidative stress and neuroinflammation are pathological events likely to be involved in PD neurodegeneration. ${ }^{1,2,3,4}$

At the clinical level, treatments currently available are essentially symptomatic, as they restore motor control by transiently enhancing DA levels in the striatum. ${ }^{5}$ Thus, neuroprotective agents, with the potential to halt or delay disease progression, are urgently required. A number of molecules developed for this purpose have demonstrated great potential in preclinical models, but none of them has led to a therapy for PD patients until now. ${ }^{6,7}$ Thus, the quest for neuroprotective drugs is still ongoing. ${ }^{8}$

To this aim, we have synthesized small non-peptide compounds that were then selected for their neuroprotective/neuritogenic potential through structure-activity relationship (SAR) studies. ${ }^{9,10}$ We initially designed hybrids of melatonin and long chain fatty acids, i.e. compounds related to natural products reported previously for having antioxidative, neuroprotective or neurotrophic effects. ${ }^{11,12}$ More specifically, we synthesized N-acylated tryptamine derivatives and screened these compounds using a cell culture system that models DA cell degeneration in PD. This resulted in the discovery of compounds having interesting anti-oxidative and neuroprotective/neuritogenic properties with, however, poor blood-brain barrier (BBB) permeability. ${ }^{10}$ To obtain compounds with better BBB permeability, we 
synthesized 6-aminoquinoxaline derivatives. This led us to find a hit compound MPAQ which was neuroprotective for DA neurons and exerted neuritogenic effects on these neurons as well. ${ }^{13}$ This compound operated indirectly through a repressive effect on astroglial cells. ${ }^{13}$ New 6-aminoquinoxalines and their N-propargyl derivatives were then designed and synthesized, and the most active one PAQ was selected on the basis of its protective activity in vitro. PAQ appeared to work via a direct effect on DA neurons through a mechanism that partly relied on ryanodine receptor activation. Finally, we also established that when given orally, PAQ was providing protection to DA neurons and their striatal terminals in a rodent model of PD. ${ }^{14}$ At this stage, we decided to explore the neuroprotective potential of $1,4,8$ triazaphenanthrenes derived synthetically from 6-aminoquinoxalines. Indeed, we recently reported that the 6-endo-dig cycloisomerization of N-propargyl-6-aminoquinoxalines leads to the expected 1,4,8- triazaphenanthrenes in a highly regioselective manner. ${ }^{15}$

\section{RESULTS \& DISCUSSION}

Several 2,3-substituted 1,4,8-triazaphenanthrenes 3a-h were prepared from the amino quinoxalines 1a-h that were described by us previously (Scheme 1). ${ }^{14} \mathrm{We}$ reported before that the phenyl ring located at position 3 of the quinoxaline core was essential for neuroprotection by 6 -aminoquinoxalines ${ }^{13}$ and that the lack of substituent at position 2 was apparently crucial to optimize this activity. ${ }^{14}$ Therefore, we designed a specific convergent route for the preparation of 3-aryl-1,4,8-triazaphenanthrenes 5c, 5f, 5g, 5k-o, based on a palladiumcatalyzed Suzuki coupling reaction of aryl-boronic acids or boronate esters with 3-chloro1,4,8-triazaphenanthrene 5i. Compound $\mathbf{5 j}$ was prepared from a Sonogashira cross-coupling with TMS-acetylene followed by methanolysis (Scheme 1). 
Scheme 1. Synthesis of 1,4,8-triazaphenanthrenes. ${ }^{a}$<smiles>C#CCNc1ccc2nc(C)c(Br)nc2c1</smiles>

3a: $\mathrm{R}=p$-tolyl

3b: $\mathrm{R}=4-\mathrm{MeO}-$ phenyl

3c: $\mathrm{R}=3,4,5-(\mathrm{MeO})_{3}$-phenyl

3d: $\mathrm{R}=4-\mathrm{Cl}$-phenyl

3e: $\mathrm{R}=3,4-(\mathrm{Cl})_{2}$-phenyl

3f: $R=4-F-$ phenyl

3g: $R=2$-naphtyl

3h: $R=4$-biphenyl<smiles>C[13CH2]c1cnc2ccc3ncc(Cl)nc3c2c1</smiles>

5c: $\mathrm{R}=3,4,5-(\mathrm{MeO})_{3}$-phenyl

5g: $R=2$-naphtyl

5k: $R=3$-quinolyl

4

$5 \mathbf{i}$

5c, 5g, 5k-p

5I: $R=1$-naphtyl

$5 \mathrm{~m}: \mathrm{R}=\mathrm{Ph}$

$5 n: R=3-H O-p h e n y l$

5o: $R=3$-pyridyl

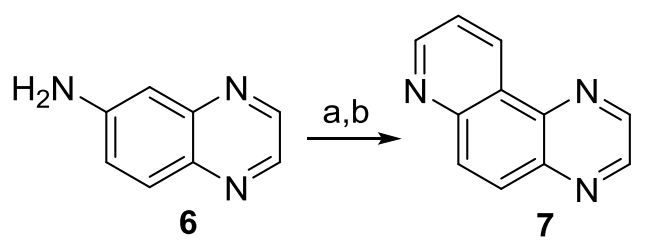

5f: $R=4-F-$ phenyl

${ }^{a}$ Reagents and conditions: (a) $\mathrm{K}_{2} \mathrm{CO}_{3}$, propargyl bromide , DMF, $100{ }^{\circ} \mathrm{C}$. (b) $\mathrm{Cu}_{2} \mathrm{O}$ or $\mathrm{CuCl}$, DMSO, $110^{\circ} \mathrm{C}$. (c) $\mathrm{ArB}(\mathrm{OH})_{2}$ or $\mathrm{ArB}(\mathrm{MIDA}),\left(\mathrm{PPh}_{3}\right)_{2} \mathrm{PdCl}_{2}, \mathrm{~K}_{2} \mathrm{CO}_{3}$, dioxane/water, reflux. (d) (i) TMSacetylene, CuI, Et $3 \mathrm{~N}$, THF $70{ }^{\circ} \mathrm{C}$, 24h. (ii) $\mathrm{K}_{2} \mathrm{CO}_{3} \mathrm{MeOH}$, reflux, 10 min. MIDA $=N$-methyliminodiacetic acid.

All synthesized 1,4,8-triazaphenanthrenes (for 3a-h, see ref. 15, and see Scheme 1) were then assessed for neuroprotection using a PD culture model that we used before and in which DA neurons degenerate selectively and spontaneously as a consequence of a mechanism involving proliferating astrocytes and calcium dyshomeostasis. ${ }^{14,16,17}$ Briefly, cultures were exposed or not for 10 days to various test molecules and neuronal rescue was assessed by counting the number of tyrosine hydroxylase $(\mathrm{TH})$ positive neurons surviving at that time.

In agreement with earlier studies, we found that more than $60 \%$ of $\mathrm{TH}^{+}$neurons initially present in these cultures had died over a 10 day period in the absence of any treatment. ${ }^{16,17}$ $\mathrm{N}^{6}, 2^{\prime}$-O-dibutyryladenosine $3^{\prime}: 5^{\prime}$ cyclic monophosphate (dbcAMP), a lipophilic derivative of 
cAMP, used as reference neuroprotectant in this model system, ${ }^{18}$ provided strong protection to vulnerable DA neurons (Figure 1). Among a series of 19 1,4,8-triazaphenanthrene derivatives, 8 of them led to significant rescue of DA neurons at $10 \mu \mathrm{M}(\mathbf{3 g}, \mathbf{5 c}, \mathbf{5 f}, \mathbf{5 g}, \mathbf{5 k}$, $\mathbf{5 m}, \mathbf{5 n}, \mathbf{5 0})$. In particular, the protection afforded by compounds $\mathbf{3 g}, \mathbf{5 c}, \mathbf{5 g}, \mathbf{5 k}, \mathbf{5 m}, \mathbf{5 n}, \mathbf{5 0}$ at $10 \mu \mathrm{M}$ was either greater than, or at least comparable to the first generation molecule PAQ, at the same concentration (see compounds whose protective activity is above red line in Figure 1). The efficacy of $\mathbf{5 g}, \mathbf{5 k}, \mathbf{5 m}, \mathbf{5 n}$ and $\mathbf{5 0}$ at $10 \mu \mathrm{M}$ was not statistically different from the reference compound dbcAMP, used at $1 \mathrm{mM}$.

Of interest, almost all molecules with a 2-hydrogen-3-aryl-1,4,8-triazaphenanthrene core structure $(\mathbf{5 c}, \mathbf{5 f}, \mathbf{5 g}, \mathbf{5 k}, \mathbf{5 m}, \mathbf{5 n}, \mathbf{5 0})$ afforded neuroprotection to DA neurons, indicating that lack of substitution at position 2 of the triazaphenanthrene group was beneficial for this activity. The only 2-hydrogen-3-aryl-1,4,8-triazaphenanthrene, which was not neuroprotective at $10 \mu \mathrm{M}$, i.e., compound $\mathbf{5 1}$, had, however, a substituent in position 3 susceptible to sterically hinder the 2-position.

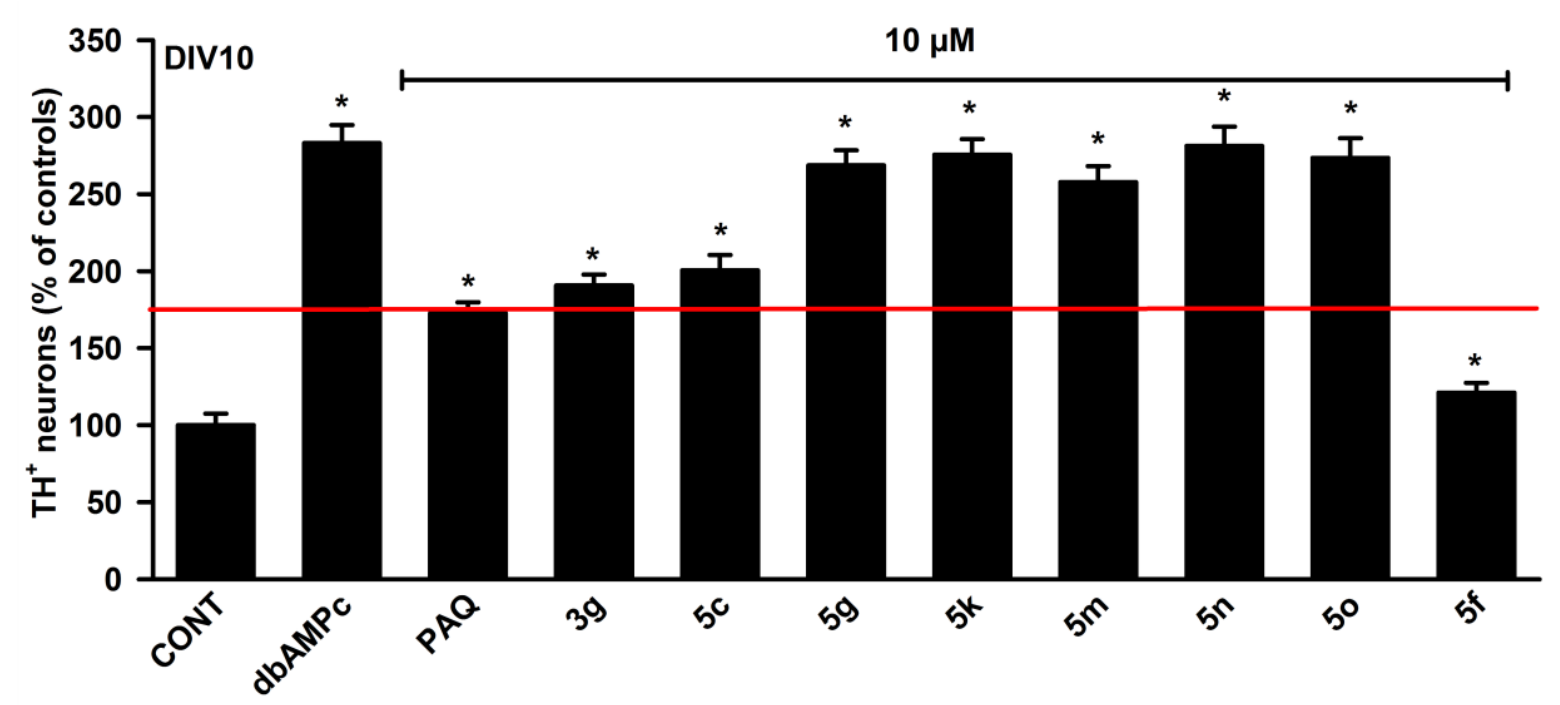

Figure 1. Screening of 1,4,8-triazaphenanthrene derivatives in a cellular system that models DA cell death in PD. Number of $\mathrm{TH}^{+}$neurons surviving after 10 days in vitro (DIV) in midbrain cultures treated or not with 1,4,8-triazaphenanthrenes $(10 \mu \mathrm{M})$. DbcAMP $(1 \mathrm{mM})$ is 
used as reference neuroprotectant for DA neurons. 1,4,8-triazaphenanthrene derivatives (3a, 3b, 3c, 3d, 3e, 3f, 3h, 5i, 5j, 5l, 7) which are inactive are not included in this figure. The efficacy of the first generation compound PAQ is signified by the red line. ${ }^{*} p<0.05 v s$ controls.<smiles></smiles>

$3 a$<smiles>Cc1nc2ccc3ncccc3c2nc1-c1ccc(Cl)cc1</smiles>

3d<smiles>COc1ccc(-c2nc3c(ccc4ncccc43)nc2C)cc1</smiles>

3b<smiles>COc1cc(-c2nc3c(ccc4ncccc43)nc2C)cc(OC)c1OC</smiles>

3c<smiles>Cc1nc2ccc3ncccc3c2nc1-c1ccc(Cl)c(Cl)c1</smiles>

$3 e$<smiles>Cc1nc2ccc3ncccc3c2nc1-c1ccc(F)cc1</smiles>

$3 \mathbf{f}$<smiles>Cc1nc2ccc3ncccc3c2nc1-c1ccc2ccccc2c1</smiles>

$3 g$<smiles>Cc1nc2ccc3ncccc3c2nc1-c1ccc(-c2ccccc2)cc1</smiles>

$3 \mathrm{~h}$<smiles>COc1cc(-c2cnc3ccc4ncccc4c3n2)cc(OC)c1OC</smiles><smiles>Fc1ccc(-c2cnc3ccc4ncccc4c3n2)cc1</smiles><smiles>c1ccc2cc(-c3cnc4ccc5ncccc5c4n3)ccc2c1</smiles>

$5 \mathrm{~g}$<smiles>Clc1cnc2ccc3ncccc3c2n1</smiles>

$5 i$<smiles>C#Cc1cnc2ccc3ncccc3c2n1</smiles>

5j<smiles>c1ccc2ncc(-c3cnc4ccc5ncccc5c4n3)cc2c1</smiles>

$5 k$<smiles>c1ccc2c(-c3cnc4ccc5ncccc5c4n3)cccc2c1</smiles>

5<smiles></smiles><smiles></smiles><smiles></smiles>

Chart 1. Chemical structures of all 1,4,8-triazaphenanthrene derivatives tested in the cellular PD model of spontaneous DA cell death. Compounds having significant protective effects towards DA neurons at $10 \mu \mathrm{M}$ are coloured in purple. PAQ is given as a reference compound. 
At this stage, we selected the 5 most active 1,4,8-triazaphenanthrene derivatives $(\mathbf{5 g}, \mathbf{5} \mathbf{k}$, $\mathbf{5 m}, \mathbf{5 n}, \mathbf{5 0}$ ) whose protective activity at $10 \mu \mathrm{M}$ was in the range of that of dbcAMP at $1 \mathrm{mM}$ (5g: $268.6 \pm 9.8 \%$; 5k: $275.5 \pm 10.2 \%$; 5m: $257.7 \pm 10.5 \%$; 5n: $281.2 \pm 12.6 \% ;$ 5o: 273.5 $\pm 12.7 \%$; dbcAMP: $283.2 \pm 11.7 \% \mathrm{TH}^{+}$neurons). To refine the screening, the protective activity of these 5 compounds was assessed at a 10 -fold lower concentration, i.e., $1 \mu \mathrm{M}$, using the same experimental paradigm (see Figure 2). All test compounds remained neuroprotective at $1 \mu \mathrm{M}$, although their efficacy was lower than at $10 \mu \mathrm{M}$. Compound $\mathbf{5 m}$ (also named PPQ) appeared to be the most effective of these compounds with a $\mathrm{EC}_{50}$ around $1.1 \mu \mathrm{M}$ and it possessed similar efficacy as PAQ, at $10 \mu \mathrm{M}$ (compound 5m $1 \mu \mathrm{M}$ : $193.4 \pm 8.6$ \% vs PAQ $10 \mu \mathrm{M}$ : $182.3 \pm 7.4 \%$ ). Interestingly compound $\mathbf{5 m}$ is also structurally closest to PAQ. Figure 3 further illustrates the neuroprotective activity of compound $\mathbf{5 m}$ on DA neurons. Note that the fiber network of $\mathrm{TH}^{+}$neurons appeared also to be denser in $\mathbf{5 m}(10$ $\mu \mathrm{M}$ )-treated cultures, suggesting a possible trophic effect of this compound on rescued DA neurons.

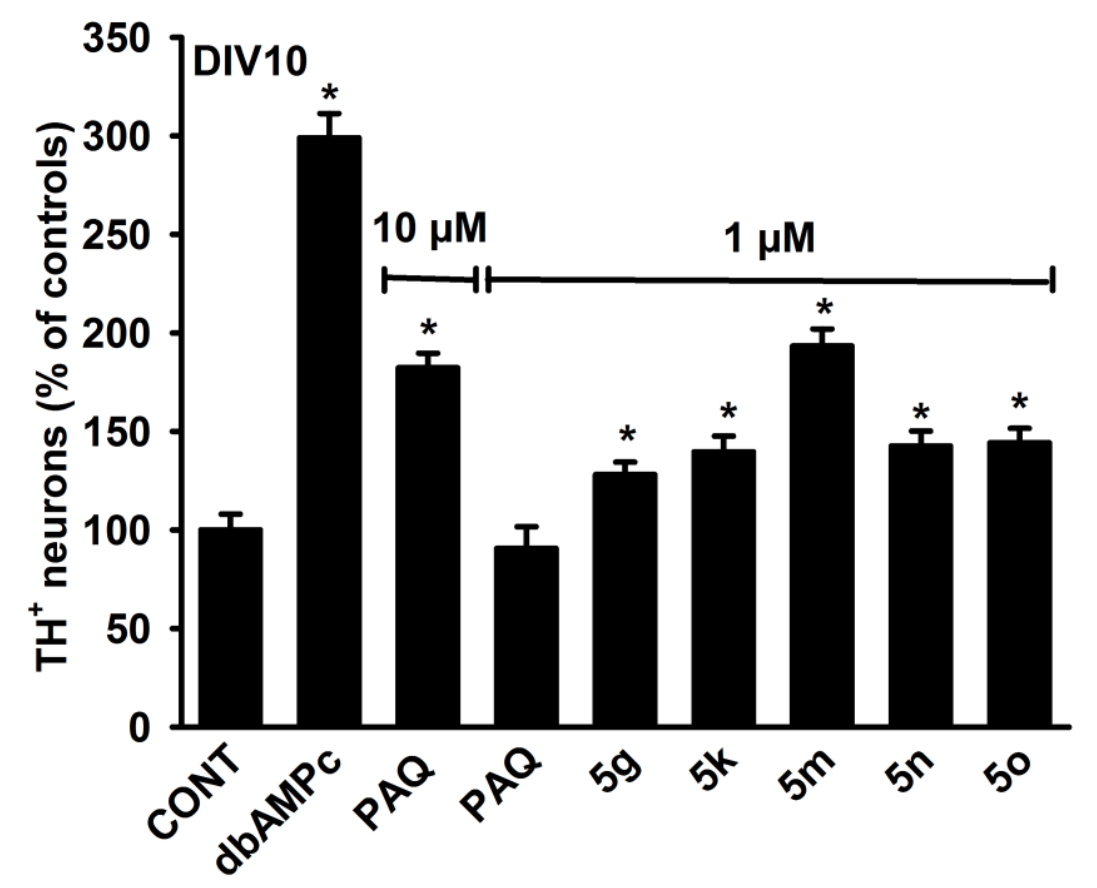


Figure 2. Evaluation of previously selected 1,4,8-triazaphenanthrene derivatives. Selected 1,4,8-triazaphenanthrene derivatives were applied to midbrain cultures at $1 \mu \mathrm{M}$ and the survival rate of DA neurons was assessed at 10 DIV. DbcAMP (1 mM) was used as reference neuroprotectant for DA neurons. $* p<0.05 v s$ control.

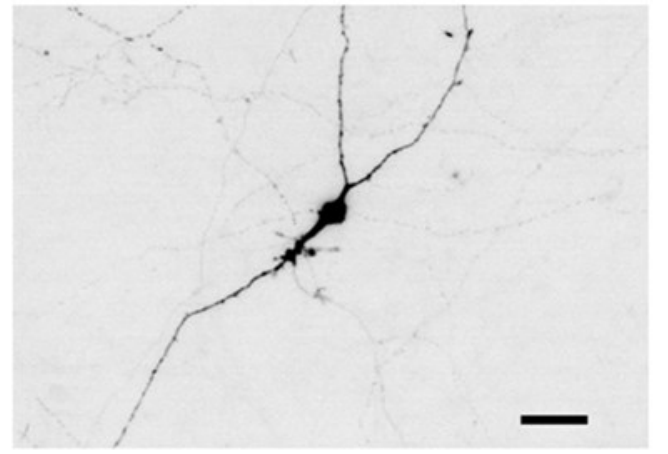

Control

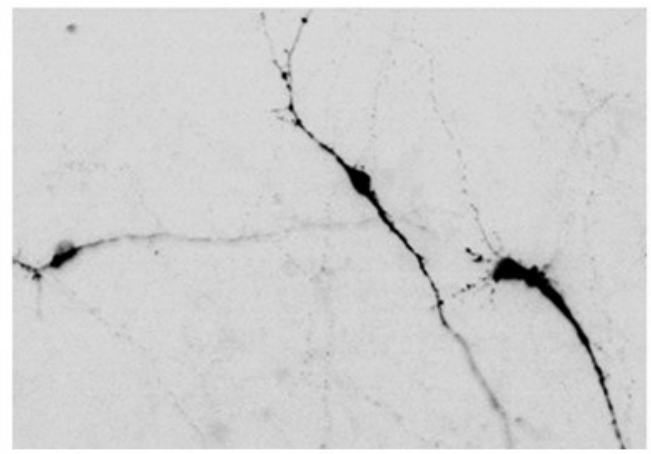

$5 \mathrm{~m} 1 \mu \mathrm{M}$

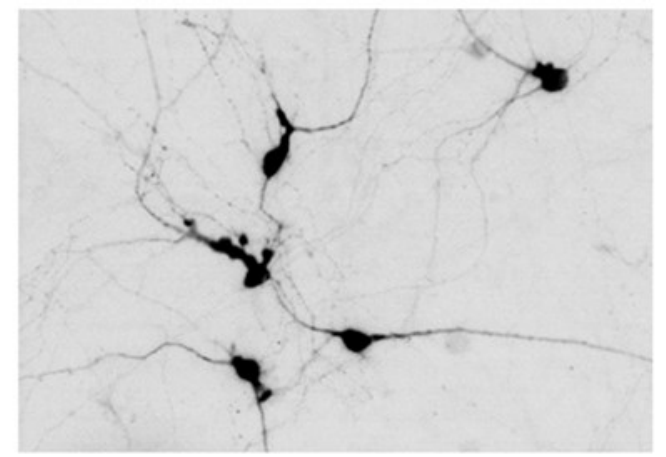

dbcAMP $1 \mathrm{mM}$

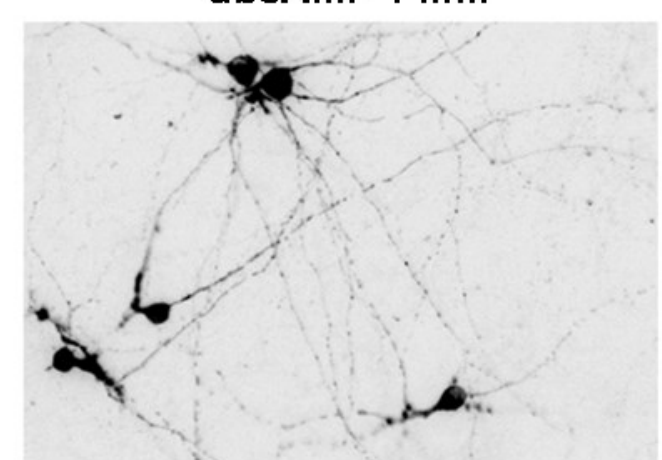

$5 \mathrm{~m} 10 \mu \mathrm{M}$

Figure 3. Neuroprotective effects of $\mathbf{5 m}$ onto DA neurons in midbrain cultures. Digitized images showing the rescuing effects of $5 \mathrm{~m}(1$ and $10 \mu \mathrm{M})$ and dbcAMP $(1 \mathrm{mM})$ for $\mathrm{TH}^{+}$ neurons in 10 DIV midbrain cultures. Illustrations are presented as inverted digitized images. Scale bar $=60 \mu \mathrm{m}$. Note that the fiber network of $\mathrm{TH}^{+}$neurons appears to be denser in $\mathbf{5 m}(10$ $\mu \mathrm{M})$-treated cultures.

In the cellular model we used here for screening purposes, we previously reported that the rescue of DA neurons could possibly result from the inhibition of proliferating glial cells, in particular, astrocytes and their progenitor cells, which represent the vast majority of cells that 
proliferate in present experimental conditions. ${ }^{19,20}$ For instance, we have shown that the reference neuroprotectant dbcAMP and also one of the previous hit compounds MPAQ were protective via a mechanism of this kind. ${ }^{13,20}$ For that reason, we wished to determine whether 5m had a similar effect. Thus, we used a DNA proliferation assay that consists in measuring the incorporation of thymidine, $\left[\right.$ methyl- ${ }^{3} \mathrm{H}$ ], a tritiated analog of the nucleoside thymidine. ${ }^{20}$ We established that $\mathbf{5 m}$ had no impact on glial cell proliferation, at $1 \mu \mathrm{M}$, a concentration already providing significant protection to DA neurons. However, glial cell proliferation was significantly reduced at concentrations of $\mathbf{5 m}$ that provide better protection to DA neurons, i.e., 3 and $10 \mu \mathrm{M}$. This suggests that the effects of $\mathbf{5 m}$ were probably partly indirect in this range of concentrations.

To better characterize the survival promoting action of $\mathbf{5 m}$ towards DA neurons, we tested whether compounds that block endoplasmic reticulum (ER) calcium release channels had an impact on the protective action of this compound. The rationale was that previous studies have shown that intracellular calcium pools released from the ER are crucially involved in the control of DA cell survival. ${ }^{1,16}$ Consistent with this hypothesis, we established that the protective effect of $5 \mathbf{m}(10 \mu \mathrm{M})$ was partially antagonized by dantrolene $(20 \mu \mathrm{M})$, a skeletal muscle relaxant drug that operates as a blocker of ER ryanodine receptor channels. This is reminiscent of earlier findings showing that neuroprotection by our previous hit compound PAQ, which is structurally related to $\mathbf{5 m}$, was also partially reversed by dantrolene. ${ }^{14}$ Remarkably, 2-aminoethoxydiphenyl borate $(2-\mathrm{APB} ; 10 \mu \mathrm{M})$, a blocker of $\mathrm{IP}_{3}$ receptors, another type of calcium release channel located on the ER, was more effective in blocking the protective effects of $\mathbf{5 m}$. Overall, these data indicate that $\mathbf{5 m}$-mediated neuroprotection required intracellular calcium mobilization. 

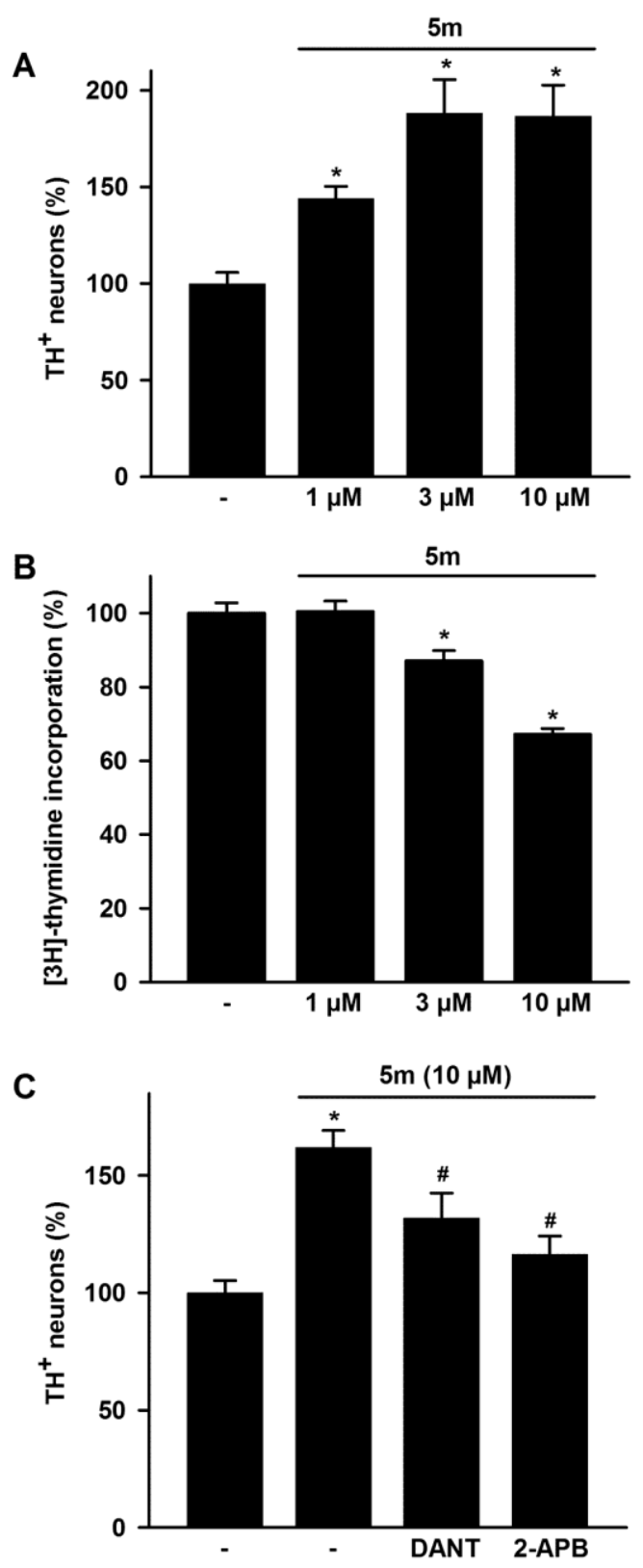

Figure 4. Neuroprotection by $\mathbf{5 m}$ results from combined effects on astroglial cells and intracellular calcium release channels. (A) Rescue of DA neurons as a function of the concentrations (1-10 $\mu \mathrm{M})$ of $\mathbf{5 m}$ applied to midbrain cultures. (B) Incorporation of tritiatedthymidine in sister cultures chronically exposed to the same concentrations of $\mathbf{5 m}$. (C) Impact of dantrolene $(20 \mu \mathrm{M})$, a blocker of ryanodine receptor channels and of 2-APB $(10 \mu \mathrm{M})$, a blocker of $\mathrm{IP}_{3}$ receptors, on the protective effects of $\mathbf{5 m}$ for DA neurons. ${ }^{*} p<0.05 v s$ corresponding control. ${ }^{\#} p<0.05$ vs $\mathbf{5 m}$-treated cultures. 
We then studied early pharmacokinetics of $\mathbf{5 m}$. For that, compound $\mathbf{5 m}$ was solubilized at $0.5 \mathrm{mg} / \mathrm{mL}$ using a $0.9 \%$ saline solution containing $10 \%$ of the formulation vehicle, cremophore EL. Then the preparation was injected i.v. at a dose of $1 \mathrm{mg} / \mathrm{kg}$ in two groups of 3 CD-1 mice, which were sacrificed either $5 \mathrm{~min}$ or $30 \mathrm{~min}$ after the injection. The purpose of the present protocol was two-fold: (i) to evaluate BBB permeability to $\mathbf{5 m}$ and (ii) to estimate this compound lifetime in the brain and plasma. After euthanasia, aliquots of plasma and brain extracts were purified and analysed by HPLC. Data summarized in Figure 5 show (i) that compound $\mathbf{5 m}$ crosses the BBB, its accumulation peaking 5 min after the injection and (ii) that it is also rapidly eliminated from the brain over a period of time of $30 \mathrm{~min}$. A similar elimination profile was observed in the plasma.
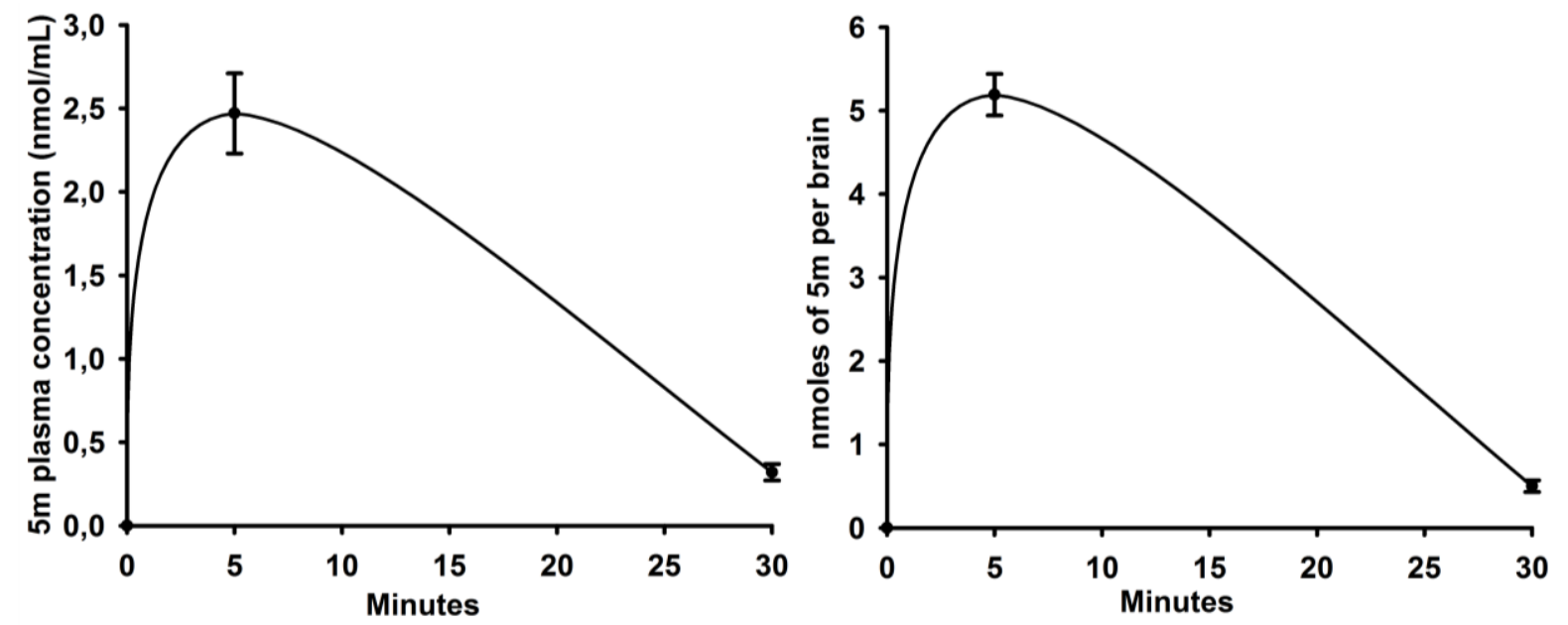

Figure 5. HPLC analysis of $\mathbf{5 m}$ in brain and plasma, after acute i.v. administration $(1 \mathrm{mg} / \mathrm{kg})$ in CD-1 mice.

In a next step, we used a mouse model of PD where DA cell death is induced by repeated injections of the neurotoxin MPTP. More specifically, C57BL/6 mice were given MPTP in a sub-chronic manner so as to generate a progressive loss of SN DA neurons and cause concurrent deficits in DA and its metabolites in the striatum. ${ }^{21,22,23}$ This experimental 
paradigm is of interest as it is thought to replicate some of the key events that contribute to PD progression. ${ }^{21,22}$

SN DA neurons were identified by immunohistochemistry of the TH enzyme, using 3,3diaminobenzidine (DAB) as a chromogen. As shown earlier, ${ }^{23,24}$ the sub-chronic administration of MPTP in C57BL/6 mice induced a substantial loss $(-39 \%)$ of $\mathrm{TH}^{+}$neurons. After 11 days of a treatment regimen with $\mathbf{5 m}$, at a dose of $2 \times 25 \mathrm{mg} / \mathrm{kg} / \mathrm{day}$ (per os), we observed an almost total rescue of $\mathrm{TH}^{+}$neurons as the survival rate of these neurons in MPTP/5m-treated mice was estimated to be $93 \pm 4 \%$ of controls $v s \quad 61 \pm 5 \%$ in MPTP/vehicle-treated mice. At a higher dosage $(2 \times 50 \mathrm{mg} / \mathrm{kg} /$ day $), 5 \mathrm{~m}$ was slightly less effective as DA cell survival reached $81 \pm 4 \%$ of controls. These results suggested that a dose of $2 \times 25 \mathrm{mg} / \mathrm{kg}$ /day (per os) was sufficient to combat efficiently the neurotoxic action of MPTP for DA neurons. The neuroprotective effect of $\mathbf{5 m}$ for SN DA neurons in MPTPtreated mice is described in detail in Figure 6.

Note that we also established that $\mathbf{5 m}$ was a poor inhibitor of monoamine oxidase-B (MAO- B), an astrocytic enzyme that transforms MPTP into a toxic metabolite $\mathrm{MPP}^{+}$, which kills DA neurons, selectively. ${ }^{21,22}$ More precisely, $\mathrm{IC}_{50}$ values for selegiline (a prototypical inhibitor for MAO-B) and for $\mathbf{5 m}$ were found to be 1.86 and $116 \mu \mathrm{M}$, respectively. This means that neuroprotection by $\mathbf{5 m}$ against MPTP was most probably not caused by a reduction in the availability of $\mathrm{MPP}^{+}$for target neurons. 

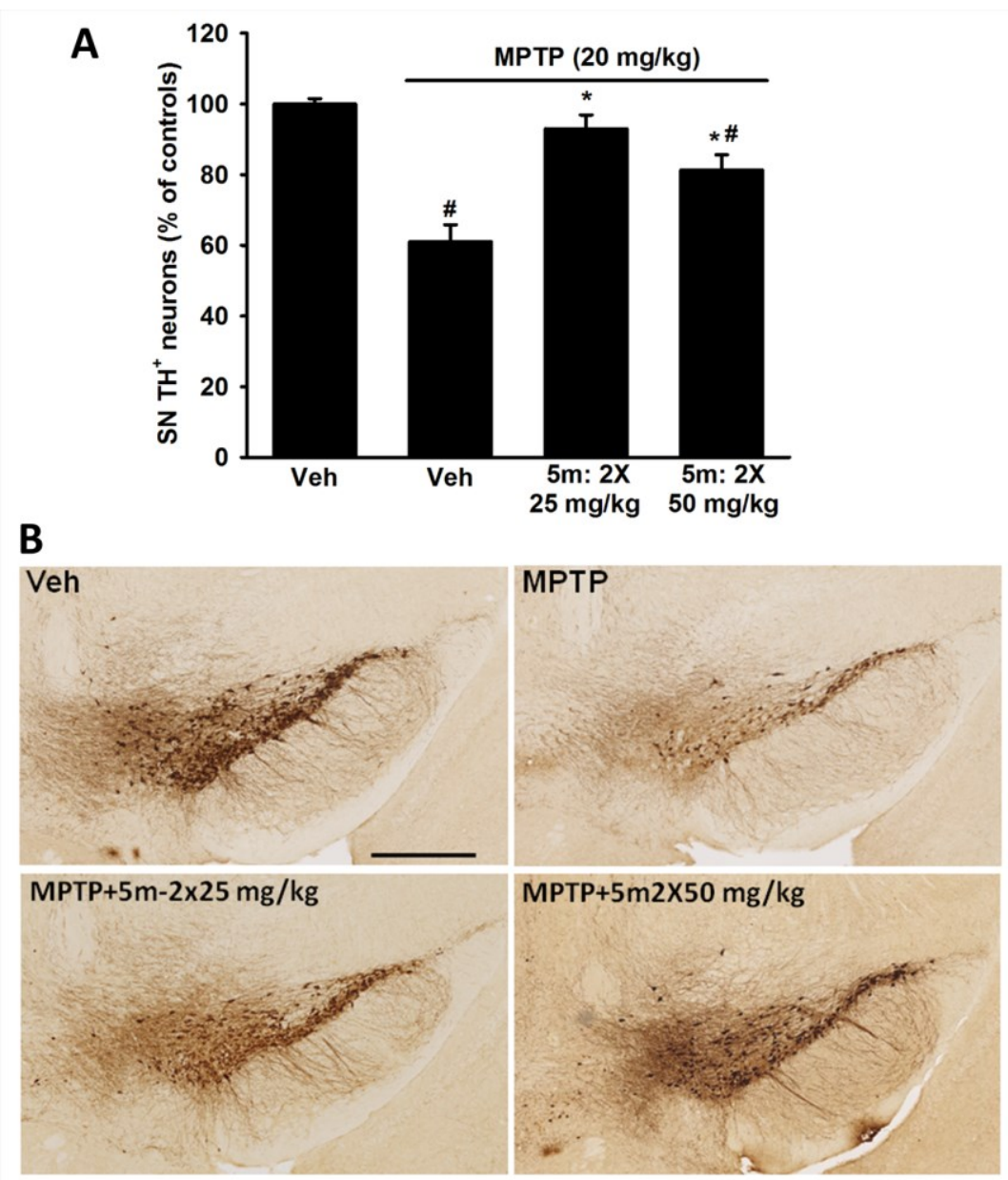

MPTP $+5 \mathrm{~m} 2 \times 50 \mathrm{mg} / \mathrm{kg}$

Figure 6. Neuroprotective effects of $\mathbf{5 m}$ for SN DA neurons in MPTP-treated mice. (A) Number of SN $\mathrm{TH}^{+}$neurons in vehicle-treated mice and in MPTP-treated mice receiving or not $\mathbf{5 m}$ for 11 days, at two different dosages $(2 \times 25,2 \times 50 \mathrm{mg} / \mathrm{kg} /$ day; p.o.). Note that only the left hemisphere was analyzed in each mouse brain. Data expressed as mean \pm SEM (n=9-12). $\# \mathrm{p}<0.05$ vs vehicle only. ${ }^{*} \mathrm{p}<0.05$ vs vehicle + MPTP $(20 \mathrm{mg} / \mathrm{kg} /$ day $)$. (B) Illustration describing the impact of $\mathbf{5 m}(2 \times 25,2 \times 50 \mathrm{mg} / \mathrm{kg} /$ day; p.o. $)$ on the number of $\mathrm{SN} \mathrm{TH} \mathrm{TH}^{+}$neurons in MPTP-treated mice in comparison to control mice. High-resolution bright-field digital images of labelled sections were acquired with a NanoZoomer Digital Scanner equipped with a 40x objective (Hamamatsu Photonics France, Massy,France) and the NDP software (Hamamatsu Photonics). Note the preservation of dendritic extensions of DA neurons in the SN of 5m-treated mice. Veh: vehicle. Scale bar $=500 \mu \mathrm{m}$. 
Finally, we also assessed DA and its metabolites in the striatum of control and MPTPtreated mice (Figure 7). In mice receiving MPTP and the vehicle, DA levels were reduced to $28 \%$ of control values. Following 11 days of treatment with $5 \mathrm{~m}(2 \times 25 \mathrm{mg} / \mathrm{kg} /$ day, p.o. $), \mathrm{DA}$ levels were substantially restored in the striatum of mice receiving MPTP (46 $\pm 3 \%)$. In the same group of mice, the levels of the DA metabolites 3,4-dihydroxyphenylacetic acid (DOPAC) and homovanillic acid (HVA) were found to be slightly increased, although not significantly in the case of DOPAC, in comparison to mice receiving MPTP and the vehicle. Note, however that $\mathbf{5 m}$ notably reduced the rise of 3,4-dihydroxyphenylacetic acid (DOPAC) + homovanillic acid (HVA) / DA ratios. This means that $\mathbf{5 m}$ limited the increase in DA turnover produced by MPTP under degenerative conditions, suggesting that this compound also partially preserved the function of the rescued neurons (see Figure 7). At the highest dosage $(2 \times 50 \mathrm{mg} / \mathrm{kg} /$ day $), 5 \mathrm{~m}$ produced comparable effects on striatal DA levels and DA turnover.
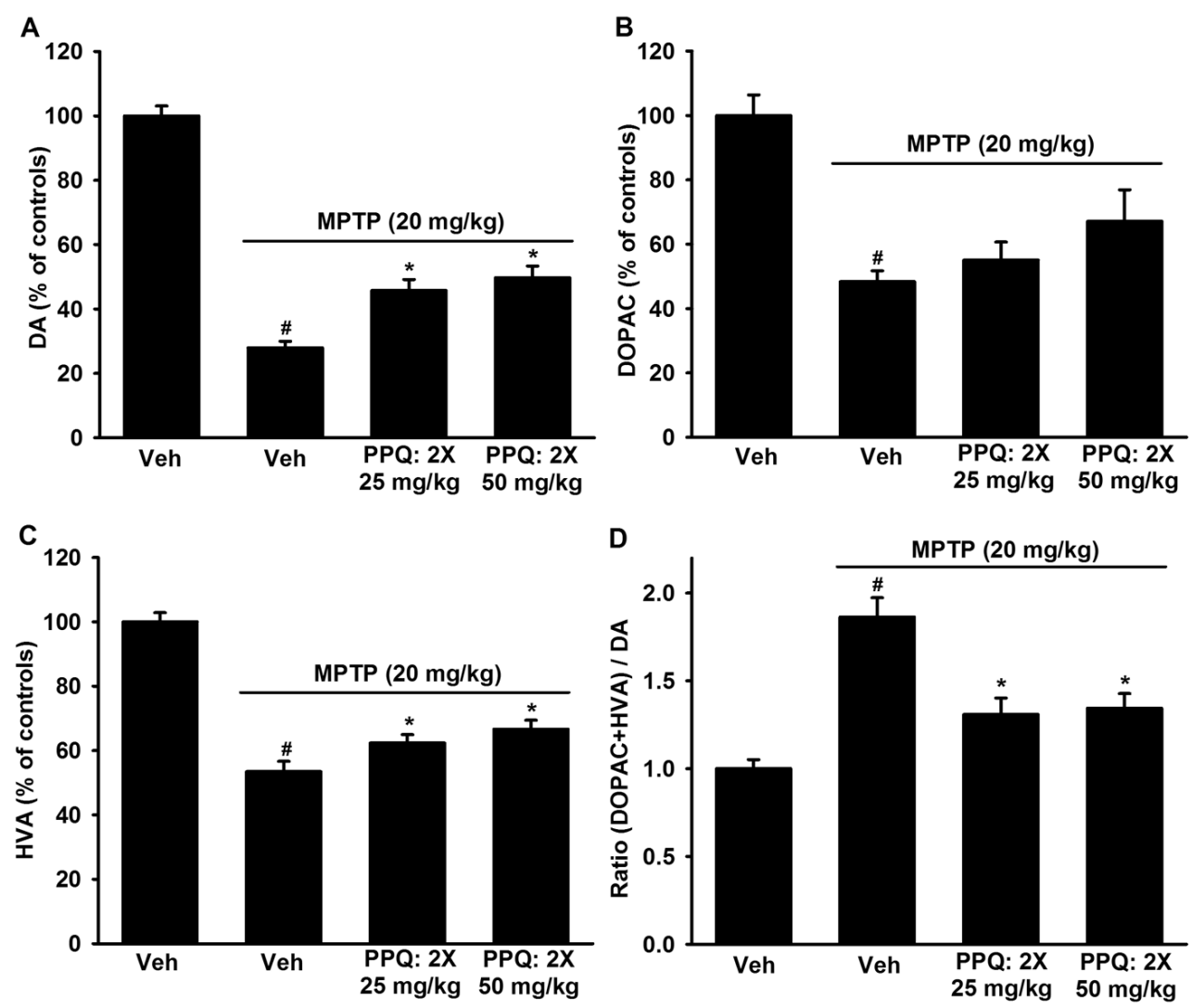
Figure 7. Effects of treatment regimens with $5 \mathbf{m}(2 \times 25,2 \times 50 \mathrm{mg} / \mathrm{kg} / \mathrm{day} ;$ p.o. $)$ on levels of DA (A), DOPAC (B) and HVA (C) in the striatum of MPTP-treated mice. (D) Effect of the same treatments as before on (DOPAC $+\mathrm{HVA}) / \mathrm{DA}$ ratios. Data expressed as mean $\pm \mathrm{SEM}$ (n=9-12). ${ }^{\#} p<0.05 v s$ vehicle only. ${ }^{*} p<0.05 v s$ vehicle + MPTP $(20 \mathrm{mg} / \mathrm{kg})$. Veh: vehicle.

To recapitulate, we synthesized 1,4,8-triazaphenanthrene derivatives through an effective strategy depending on palladium-catalyzed Suzuki cross-coupling of arylboronic acids with 3chloro-1,4,8-triazaphenanthrene. The desired compounds were obtained in moderate to good yields. The newly synthesized compounds were evaluated using a cell culture system that models DA cell death in PD. ${ }^{16,25}$ A number of molecules provided efficient protection to DA neurons. Note, however, that among 1,4,8-triazaphenanthrenes, the presence of a methyl group at position 2 of the heterocyclic scaffold gave rise to compounds that were much less active, compared to the unsubstituted ones. Overall, 5 compounds exerted strong neuroprotective effects at $10 \mu \mathrm{M}$, and lower but still significant effects at $1 \mu \mathrm{M},(\mathbf{5 g}, \mathbf{5 k}, \mathbf{5 m}$, 5n, 5o). Because $\mathbf{5 m}$ retained better neuroprotective efficacy in the low concentration range (i.e., at $1 \mu \mathrm{M})$ than its congeners $(\mathbf{5 g}, \mathbf{5 k}, \mathbf{5 n}, \mathbf{5 0})$, we selected $\mathbf{5 m}$ for further investigations.

Since in the present culture model, dividing astroglial cells exert deleterious effects onto DA neurons, ${ }^{16,25}$ we evaluated the potential of $\mathbf{5 m}$ to act via a repressive effect on these cells. 5m had no impact on glial cell proliferation at $1 \mu \mathrm{M}$, a low effective concentration of this compound. However, glial cell proliferation was moderately but significantly reduced when $5 \mathbf{m}$ was used at concentrations of 3 and $10 \mu \mathrm{M}$, which provide better protection to DA neurons. Thus, we may assume that neuroprotection by $\mathbf{5 m}$ resulted from a direct effect on DA neurons, at low effective concentrations of this compound whereas at higher concentrations, DA cell rescue was improved through the repression of dividing astroglial cells. 
Previous studies also suggested that intracellular calcium stored in the ER may enable DA neurons to control their own survival. ${ }^{1,25,26}$ In relation to that, we established that the blockade of ER calcium release channels caused a significant reduction in $\mathbf{5 m}$-mediated DA cell rescue. In this context, the antagonist of $\mathrm{IP}_{3}$ receptors, $2-\mathrm{APB}$ was more effective than dantrolene a blocker of ryanodine receptors channels. It appears, therefore, that ER calcium mobilization was involved in $\mathbf{5 m}$-mediated neuroprotection. Whether the calcium release effect of $\mathbf{5 m}$ was related in some way to that exerted on proliferating astrocytes remains, however, to be determined.

Through pharmacokinetics studies, we showed that $\mathbf{5 m}$ reaches the brain after i.v. administration $(1 \mathrm{mg} / \mathrm{kg})$ to mice. Even if eliminated relatively rapidly from the brain, the strong neuroprotective potential of $\mathbf{5 m}$ observed in vitro led us to further investigate the efficacy of this compound after oral administration in an animal model of PD.

More specifically, we studied the in vivo effects of $\mathbf{5 m}$ in the MPTP mouse model of PD. ${ }^{21,22}$ When C57BL/6 mice were given MPTP according to a sub-chronic regimen of administration, we found that the loss nigrostriatal DA neurons was quite substantial, at the time of sacrifice, i.e., 3 days after the last MPTP injection. The loss of DA cell bodies in the SN resulted in a profound reduction of DA levels in the striatum and in a significant increase in DA turnover as revealed by higher (DOPAC+HVA)/DA ratios. After forced oral feeding of mice twice daily with $\mathbf{5 m}$ for 11 days (starting 3 days before and finishing 3 days after initiation and termination of MPTP treatment, respectively), we observed that SN DA cell bodies were robustly protected from degeneration. Note that the integrity of the dendritic network was also well preserved by $\mathbf{5 m}$ in these neurons. The treatment with $\mathbf{5 m}$ only partially restored DA levels in the striatum and limited the rise of the (DOPAC+HVA)/DA ratios, at both dosage regimen $(2 \times 25$ and $2 \times 50 \mathrm{mg} / \mathrm{kg} /$ day $)$, which suggests that the function of rescued DA neurons was partly preserved under these conditions of treatment. The 
observation that $\mathbf{5 m}$ was more efficacious to protect DA cell bodies in the SN than to preserve DA levels in the striatum may be attributable to the fact that axonal nerve endings are generally more vulnerable than corresponding cell bodies in the process of neurodegeneration. ${ }^{27}$

Because the bioconversion of MPTP into its toxic metabolite $\mathrm{MPP}^{+}$occurs through the enzyme MAO-B located within brain astrocytes, ${ }^{21,22}$ we wished to determine whether MAO-B inhibition could account for $\mathbf{5 m}$-mediated neuroprotection against MPTP. In fact, $\mathbf{5 m}$ proved to be a poor MAO-B inhibitor in contrast to the reference molecule selegiline, thus indicating that $\mathbf{5 m}$ was unlikely to be protective by decreasing $\mathrm{MPP}^{+}$availability for DA neurons in MPTP-intoxicated mice. This confirmed the view that $\mathbf{5 m}$ was acting as a true neuroprotectant for vulnerable DA neurons.

In conclusion, we have synthesized 1,4,8-triazaphenanthrene derivatives, and after evaluating their effects in a cell culture system of spontaneous and selective DA cell death, we selected the most active of them, $\mathbf{5 m}$. This compound seemed to operate through a dual mechanism involving intracellular calcium release channels and astroglial cells. Besides, we established that an oral treatment regimen with $\mathbf{5 m}$ was effective in reducing lesions of the nigrostriatal pathway in a mouse model of $\mathrm{PD}$, thus confirming the ability of $\mathbf{5 m}$ to act as a neuroprotectant for DA neurons. Additional preclinical studies will be needed, however, to confirm that $\mathbf{5 m}$ is of potential interest for PD treatment.

\section{EXPERIMENTAL SECTION}

Chemistry. General. Tetrahydrofuran was distilled over sodium/benzophenone and under nitrogen atmosphere prior to use. Reactions involving moisture-sensitive reactants were performed under nitrogen atmosphere using oven-dried glassware. Routine monitoring of reactions was performed by thin-layer chromatography, using Riedel-deHaën, S, $0.063 \mathrm{~mm}$, 
0.032 silica gel plates, using a UV-lamp at $254 \mathrm{~nm}$ to see UV active compounds. Complementary TLC analysis was performed with a dying reagent by dipping the plate into a $10 \%$ sulfomolybdic acid solution or o-vanillin in $\mathrm{EtOH} / \mathrm{H}_{2} \mathrm{SO}_{4}(95: 5)$ and then heated to stain or dipped a few min in a mixture of silica and iodide. Silica gel flash chromatography was performed using Riedel-deHaën, S, $0.063 \mathrm{~mm}, 0.032$ silica under moderate pressure with the appropriate solvent giving us a migrating front (Rf) in the range of 0.2-0.3. ${ }^{1} \mathrm{H}$ NMR spectra were recorded as $\mathrm{CDCl}_{3}$ solutions using BRUKER AR $200 \mathrm{P}$ (200 MHz), BRUKER AVANCE $300(300 \mathrm{MHz})$ and AM-400 (400 MHz) spectrometers. Chemical shifts were expressed in parts per million (ppm, $\delta$ ), downfield from tetramethylsilane (TMS) and were referenced to $\mathrm{CHCl}_{3}(7.26 \mathrm{ppm})$ as internal standard. ${ }^{13} \mathrm{C}$ NMR spectra were recorded as $\mathrm{CDCl}_{3}$ solutions with BRUKER AR $200 \mathrm{P}(50 \mathrm{MHz})$ and AM-400 (100 MHz) spectrometers. Chemical shifts were expressed in parts per million (ppm, $\delta$ ), downfield from tetramethylsilane (TMS) and were referenced to $\mathrm{CDCl}_{3}(77.0 \mathrm{ppm})$ as internal standard. Mass spectra (MS) were measured on a Nermag- Sidar R10-10C spectrometer with a quadrupole filter. High Resolution Mass Spectra (HRMS) were obtained from a Xevo Q-Tof Waters ${ }^{\circledR}$ spectrometer. Compounds 1a-h, 4, 6 and PAQ were described in ref.14 whereas compounds 2a-h, 3a-h, 7 were reported in ref. 15 .

\section{Compound 5i}

To a mixture of -6-aminoquinoxaline 4 (6.0g, 33.4 mmol, 1 equiv.), $\mathrm{K}_{2} \mathrm{CO}_{3}$ (4.6g, $33.4 \mathrm{mmol}$, 1 equiv.) in anhydrous DMF (20 mL) under inert atmosphere was added propargyl bromide (5.6 mL, 1.5 equiv., $80 \%$ in toluene) and the reaction mixture was heated at $100^{\circ} \mathrm{C}$ for $24 \mathrm{~h}$. After cooling to room temperature, the mixture was diluted with water, extracted with ethyl acetate, washed with brine, dried over $\mathrm{MgSO}_{4}$, filtered and concentrated in vacuo. The residue 
was purified by silica gel flash chromatography $\left(\mathrm{CH}_{2} \mathrm{Cl}_{2}\right.$ : EtOAc, $90: 10$ to $\left.80: 20\right)$ to afford mono-propargyl derivative $(2.7 \mathrm{~g}, 12.4 \mathrm{mmol}, 37 \%)$ as a brownish yellow solid.

To a solution $N$-propargyl derivative (1.28 g, $5.89 \mathrm{mmol}, 1$ equiv.) in DMSO (20 mL) was added $\mathrm{CuCl}$ (583 mg, $5.89 \mathrm{mmol}, 1$ equiv.) and the reaction mixture was heated at $120{ }^{\circ} \mathrm{C}$ for 3h. The reaction mixture was quenched at $\mathrm{rt}$ with $10 \% \mathrm{NH}_{3}$ in water $(50 \mathrm{~mL})$, stirred $10 \mathrm{~min}$, filtered over celite ${ }^{\circledR}$, washed with EtOAc. The aqueous layer was extracted with EtOAc and the combined organics phases were washed with brine $(2 \times 40 \mathrm{~mL})$, dried over $\mathrm{MgSO}_{4}$, filtered and concentrated. Purification on silica gel chromatography, $\left(\mathrm{CH}_{2} \mathrm{Cl}_{2}\right.$ : EtOAc, 80:20) afforded compound $\mathbf{5 i}, 1.03 \mathrm{~g}, 74 \%)$.

${ }^{1} \mathrm{H}$ NMR $\left(300 \mathrm{MHz}, \mathrm{CDCl}_{3}\right) \delta 9.40(\mathrm{ddd}, J=8.3,1.7,0.6 \mathrm{~Hz}, 1 \mathrm{H}), 9.12(\mathrm{dd}, J=4.4,1.7 \mathrm{~Hz}$, $1 \mathrm{H}), 8.91(\mathrm{~s}, 1 \mathrm{H}), 8.31(\mathrm{dd}, J=9.3,0.6 \mathrm{~Hz}, 1 \mathrm{H}), 8.20(\mathrm{~d}, J=9.3 \mathrm{~Hz}, 1 \mathrm{H}), 7.69(\mathrm{dd}, J=8.3$, $4.4 \mathrm{~Hz}, 1 \mathrm{H}) .{ }^{13} \mathrm{C} \mathrm{NMR}\left(75 \mathrm{MHz}, \mathrm{CDCl}_{3}\right) \delta 152.52,149.36,147.42,144.95,140.28,140.13$, 133.10, 132.92, 129.73, 125.43, 122.53. IR $\left(\mathrm{cm}^{-1}\right): 3049,1493,1207,1146,900,841$. HRMS (ESI), calcd m/z for $[\mathrm{M}+\mathrm{H}]^{+} \mathrm{C}_{11} \mathrm{H}_{7} \mathrm{~N}_{3}{ }^{35} \mathrm{Cl}: 216.0329$, found: 216.0323 .

General procedure for the synthesis of compounds $5 \mathrm{c}, 5 \mathrm{~g}, 5 \mathrm{k}-0$. To a suspension of compound 5i (1 equiv.), $\mathrm{K}_{2} \mathrm{CO}_{3}$ (2.6 equiv.), boronic acid or MIDA boronate (1.3 equiv.), $\mathrm{PdCl}_{2}\left(\mathrm{PPh}_{3}\right)_{2}(0.03$ equiv. $)$ in a dioxane $: \mathrm{H}_{2} \mathrm{O}$ mixture $(8: 2 \mathrm{~mL} / \mathrm{mmol}$ of $\mathbf{5 i})$ is refluxed for 1h. After cooling, the reaction mixture was extracted three times with EtOAc, washed once with $10 \%$ aqueous $\mathrm{K}_{2} \mathrm{CO}_{3}$. The organic solution was dried over $\mathrm{MgSO}_{4}$, filtered and concentrated. The residue was then purified on a silica gel column to give compound $\mathbf{5 c}, \mathbf{5} \mathbf{g}$ or 5k-o as a beige solid.

Compound 5c (155.2 mg, 96\%). ${ }^{1} \mathrm{H}$ NMR (300 MHz, $\left.\mathrm{CDCl}_{3}\right): \delta 9.59$ (ddd, $J=8.3,1.7,0.5$ Hz, 1H), 9.39 (s, 1H), 9.12 (dd, $J=4.4,1.7 \mathrm{~Hz}, 1 \mathrm{H}), 8.29$ (dd, $J=9.4,0.5 \mathrm{~Hz}, 1 \mathrm{H}), 8.23$ (d, $J$ 
$=9.4 \mathrm{~Hz}, 1 \mathrm{H}), 7.71(\mathrm{dd}, J=8.3,4.4 \mathrm{~Hz}, 1 \mathrm{H}), 7.55(\mathrm{~s}, 2 \mathrm{H}), 4.06(\mathrm{~s}, 6 \mathrm{H}), 3.97(\mathrm{~s}, 2 \mathrm{H}) .{ }^{13} \mathrm{C}$ NMR $\left(75 \mathrm{MHz}, \mathrm{CDCl}_{3}\right) \delta 154.11,152.12,150.63,149.67,142.97,140.79,140.66,139.96$, $132.91,132.47,132.16,130.44,126.63,122.31,105.11,61.22,56.62$. IR 3000-2837, 1588, 1494, 1343, 1235, 1127, 853. HRMS (ESI), calcd m/z for $[\mathrm{M}+\mathrm{H}]^{+} \mathrm{C}_{20} \mathrm{H}_{18} \mathrm{~N}_{3}$ : 348.1348 , found: 348.1353 .

Compound 5f (124.1 mg, 92\%). ${ }^{1} \mathrm{H}$ NMR $\left(300 \mathrm{MHz}, \mathrm{CDCl}_{3}\right) \delta 9.58(\mathrm{ddd}, J=8.3,1.7,0.6$ $\mathrm{Hz}, 1 \mathrm{H}), 9.38$ (s, 1H), $9.10(\mathrm{dd}, J=4.4,1.7 \mathrm{~Hz}, 1 \mathrm{H}), 8.31(\mathrm{dd}, J=9.0,5.4 \mathrm{~Hz}, 2 \mathrm{H}), 8.27$ (dd, $J=9.3,0.6 \mathrm{~Hz}, 2 \mathrm{H}), 8.20(\mathrm{~d}, J=9.3 \mathrm{~Hz}, 2 \mathrm{H}), 7.68(\mathrm{dd}, J=8.3,4.4 \mathrm{~Hz}, 1 \mathrm{H}), 7.28(\mathrm{t}, J=8.5$ $\mathrm{Hz}, 2 \mathrm{H}) .{ }^{13} \mathrm{C} \mathrm{NMR}\left(75 \mathrm{MHz}, \mathrm{CDCl}_{3}\right) \delta 164.35(\mathrm{~d}, J=251.1 \mathrm{~Hz}), 152.00,149.58(\mathrm{~d}, J=14.0$ $\mathrm{Hz}), 142.49,140.64,139.84,132.74,132.48,130.19,129.40$ (d, $J=8.5 \mathrm{~Hz}), 126.47,122.18$, $116.30(\mathrm{~d}, J=21.7 \mathrm{~Hz}) .{ }^{19} \mathrm{~F}$ NMR $\left(188 \mathrm{MHz}, \mathrm{CDCl}_{3}\right) \delta 110.66(\mathrm{tt}, J=8.5,5.4 \mathrm{~Hz})$. HRMS (ESI), calcd m/z for $[\mathrm{M}+\mathrm{H}]^{+} \mathrm{C}_{17} \mathrm{H}_{11} \mathrm{~N}_{3} \mathrm{~F}: 276.0937$, found: 276.0937 .

Compound 5g (121.0 mg, 85\%). ${ }^{1} \mathrm{H}$ NMR $\left(300 \mathrm{MHz}, \mathrm{CDCl}_{3}\right) \delta \mathrm{ppm}: 9.70(\mathrm{dd}, J=8.2,1.7$ $\mathrm{Hz}, 1 \mathrm{H}), 9.60$ (s, 1H), 9.13 (dd, $J=4.5,1.6 \mathrm{~Hz}, 1 \mathrm{H}), 8.76$ (brs, $1 \mathrm{H}), 8.50$ (dd, $J=9.6,1.6 \mathrm{~Hz}$, $1 \mathrm{H}), 8.30(\mathrm{~d}, J=9.4 \mathrm{~Hz}, 1 \mathrm{H}), 8.26(\mathrm{~d}, J=9.4 \mathrm{~Hz}, 1 \mathrm{H}), 8.07(\mathrm{~d}, J=8.2 \mathrm{~Hz}, 1 \mathrm{H}), 8.05(\mathrm{t}, J=$ $4.3 \mathrm{~Hz}, 1 \mathrm{H}), 7.94(\mathrm{~m}, 1 \mathrm{H}), 7.73(\mathrm{dd}, J=8.2,4.3 \mathrm{~Hz}, 1 \mathrm{H}), 7.60(\mathrm{dd}, J=3.5,6.6 \mathrm{~Hz}, 1 \mathrm{H}), 7.58$ $(\mathrm{dd}, J=3.5,6.6 \mathrm{~Hz}, 1 \mathrm{H}),{ }^{13} \mathrm{C} \mathrm{NMR}\left(75 \mathrm{MHz}, \mathrm{CDCl}_{3}\right) \delta \mathrm{ppm}: 152.0,152.0,150.7,149.5$, $143.1,140.7,140.0,134.2,133.9,133.4,132.9,130.3,129.1,128.9,127.8,127.4,126.8$, 126.6, 124.4, 122.2, IR : 1728, 1701, 1539, 1499, 1380 1287, 1237, 1210, 1090, 1016, 845, 825, 791, 751, 732. HRMS (ESI), calcd $\mathrm{m} / \mathrm{z}$ for $[\mathrm{M}+\mathrm{H}]^{+} \mathrm{C}_{21} \mathrm{H}_{14} \mathrm{~N}_{3}$ : 308.1188, found: 308.1188. 
Compound 5k (123.0 mg, 86\%). ${ }^{1} \mathrm{H}$ NMR (300 MHz, DMSO) $\delta 10.01$ (d, $\left.J=1.9 \mathrm{~Hz}, 1 \mathrm{H}\right)$, $9.95(\mathrm{~s}, 1 \mathrm{H}), 9.71(\mathrm{dd}, J=8.3,1.5 \mathrm{~Hz}, 1 \mathrm{H}), 9.49(\mathrm{~d}, J=2.0 \mathrm{~Hz}, 1 \mathrm{H}), 9.17(\mathrm{dd}, J=4.2,1.5$ $\mathrm{Hz}, 1 \mathrm{H}), 8.31(\mathrm{~s}, 2 \mathrm{H}), 8.21(\mathrm{~d}, J=7.4 \mathrm{~Hz}, 1 \mathrm{H}), 8.15(\mathrm{~d}, J=8.3 \mathrm{~Hz}, 1 \mathrm{H}), 7.94-7.85(\mathrm{~m}, 2 \mathrm{H})$, 7.74 (ddd, $J=7.9,6.9,0.9 \mathrm{~Hz}, 1 \mathrm{H}) .{ }^{13} \mathrm{C}$ NMR (75 MHz, DMSO) $\delta 152.40,149.21,148.80$, $148.27,148.09,143.86,140.47,139.10,135.05,132.57(2 \mathrm{C}), 130.97,130.05,129.08,128.88$, $128.67,127.49,127.33,125.76,122.94,39.52$. IR : 3048,1572, 1498, 1300, 1090, 1066, 904, 847, 790, 753. HRMS (ESI), calcd m/z for [M+H] ${ }^{+} \mathrm{C}_{20} \mathrm{H}_{13} \mathrm{~N}_{4}: 309.1140$, found: 309.1140 .

Compound 5l (110.0 mg, 78\%). ${ }^{1} \mathrm{H}$ NMR (300 MHz, $\left.\mathrm{CDCl}_{3}\right) \delta 9.57$ (ddd, $J=8.3,1.7,0.6$ $\mathrm{Hz}, 1 \mathrm{H}), 9.29(\mathrm{~s}, 1 \mathrm{H}), 9.12(\mathrm{dd}, J=4.4,1.8 \mathrm{~Hz}, 1 \mathrm{H}), 8.37(\mathrm{dd}, J=9.3,0.5 \mathrm{~Hz}, 1 \mathrm{H}), 8.34(\mathrm{~m}$, $1 \mathrm{H}), 8.31(\mathrm{dd}, J=9.3 \mathrm{~Hz}, 1 \mathrm{H}), 8.05(\mathrm{brd}, J=8.2 \mathrm{~Hz}, 1 \mathrm{H}), 8.00(\mathrm{dd}, J=6.9,2.5 \mathrm{~Hz}, 1 \mathrm{H}), 7.86$ $(\mathrm{dd}, J=7.1,1.2 \mathrm{~Hz}, 1 \mathrm{H}), 7.72-7.63(\mathrm{~m}, 2 \mathrm{H}), 7.63-7.51(\mathrm{~m}, 2 \mathrm{H}) .{ }^{13} \mathrm{C}$ NMR $(75 \mathrm{MHz}$, $\left.\mathrm{CDCl}_{3}\right) \delta 153.32,152.00,149.43,146.47,140.46,139.92,134.98,134.12,132.97,132.79$, $131.21,130.32,130.27,128.86,128.69,127.17,126.61,126.36,125.41,125.13,122.32$. IR 3000-2800, 1755, 1586, 1574, 1495, 1377, 1317, 1303, 1088, 1055, 899, 844, 795, 775, 732. HRMS (ESI), calcd m/z for [M+H] ${ }^{+} \mathrm{C}_{21} \mathrm{H}_{14} \mathrm{~N}_{3}: 308.1188$, found: 308.1187.

Compound 5m (106.3 mg, 89\%). ${ }^{1} \mathrm{H}$ NMR (400 MHz, $\left.\mathrm{CDCl}_{3}\right) \delta 9.66(\mathrm{~d}, J=8.3 \mathrm{~Hz}, 1 \mathrm{H})$, $9.46(\mathrm{~s}, 1 \mathrm{H}), 9.15$ (brs, $1 \mathrm{H}), 8.33(\mathrm{dd}, J=8.3$ et $1.5 \mathrm{~Hz}, 2 \mathrm{H}), 8.26(\mathrm{t}, J=8.5 \mathrm{~Hz}, 2 \mathrm{H}), 7.72$ (brm, 1H), $7.61(\mathrm{~m}, 3 \mathrm{H}) .{ }^{13} \mathrm{C} \mathrm{NMR}\left(100 \mathrm{MHz}, \mathrm{CDCl}_{3}\right) \delta 122.3$ (br), 126.8 (br), 127.5 (2C), 129.2 (2C), 130.2, 130.3, 132.4, 132.8, 136.5, 140.1, 140.7, 142.9, 149.7 (br), 150.7, 151.9 (br). HRMS (ESI), calcd m/z for [M+H] ${ }^{+} \mathrm{C}_{17} \mathrm{H}_{12} \mathrm{~N}_{3}: 258.1031$, found: 258.1028 .

Compound 5n (40.0 mg, 32\%). ${ }^{1} \mathrm{H}$ NMR (300 MHz, DMSO) $\delta 9.80$ (brs, 1H, OH), 9.65 (s, $1 \mathrm{H}), 9.56(\mathrm{dd}, J=8.3,1.7 \mathrm{~Hz}, 1 \mathrm{H}), 9.14(\mathrm{dd}, J=4.3,1.7 \mathrm{~Hz}, 1 \mathrm{H}), 8.26(\mathrm{~s}, 2 \mathrm{H}), 7.93-7.87$ (m, 
2H), $7.88(\mathrm{dd}, J=8.4,4.4 \mathrm{~Hz}, 1 \mathrm{H}), 7.44(\mathrm{t}, J=8.2 \mathrm{~Hz}, 1 \mathrm{H}), 7.01(\mathrm{ddd}, J=8.2,2,1 \mathrm{~Hz} 1 \mathrm{H})$. ${ }^{13} \mathrm{C}$ NMR (75 MHz, DMSO) $\delta 158.14,152.20,150.10,148.75,143.50,140.15,138.90$, $137.17,132.07,131.99,130.26,130.03,125.76,122.78,118.26,117.67,114.04,39.52$. HRMS (ESI), calcd m/z for $[\mathrm{M}+\mathrm{H}]^{+} \mathrm{C}_{17} \mathrm{H}_{12} \mathrm{~N}_{3} \mathrm{O}: 274.0980$, found : 274.0978.

Compound $50(95.0 \mathrm{mg}, 79 \%) .{ }^{1} \mathrm{H}$ NMR $\left(300 \mathrm{MHz}, \mathrm{CDCl}_{3}\right) \delta 9.61$ (ddd, $J=8.3,1.7,0.6$ Hz, 1H), $9.55(\mathrm{~d}, J=1.7 \mathrm{~Hz}, 1 \mathrm{H}), 9.46(\mathrm{~s}, 1 \mathrm{H}), 9.13(\mathrm{dd}, J=4.4,1.8 \mathrm{~Hz}, 1 \mathrm{H}), 8.80(\mathrm{dd}, J=$ 4.7, $1.2 \mathrm{~Hz}, 1 \mathrm{H}), 8.61(\mathrm{ddd}, J=8.0,2.2,1.7 \mathrm{~Hz}, 1 \mathrm{H}), 8.32(\mathrm{dd}, J=9.3,0.5 \mathrm{~Hz}, 1 \mathrm{H}), 8.25(\mathrm{~d}$, $J=9.3 \mathrm{~Hz}, 1 \mathrm{H}), 7.72(\mathrm{dd}, J=8.3,4.4 \mathrm{~Hz}, 1 \mathrm{H}), 7.54(\mathrm{ddd}, J=8.0,4.9,0.7 \mathrm{~Hz}, 1 \mathrm{H}) .{ }^{13} \mathrm{C}$ NMR $\left(75 \mathrm{MHz}, \mathrm{CDCl}_{3}\right) \delta 152.21,151.12,149.52,148.76,148.38,142.45,141.28,140.12$, $134.67,133.17,132.78,132.26,130.18,126.43,123.90,122.40$. IR : $3040,1614,1589,1496$, 1477, 1391, 1304, 1289, 1095, 1075, 845, 790, 702. HRMS (ESI), calcd m/z for $[\mathrm{M}+\mathrm{H}]^{+}$ $\mathrm{C}_{16} \mathrm{H}_{11} \mathrm{~N}_{4}: 259.0984$, found: 259.0984 .

Compound 5j. To compound 5i (100 mg, 0.464 mmol, 1 equiv.), CuI (4.3 mg, 0.0232 mmol, 0.05 equiv.), $\mathrm{PdCl}_{2}\left(\mathrm{PPh}_{3}\right)_{2}(6.5 \mathrm{mg}, 0.0093 \mathrm{mmol}, 0.02$ equiv.) in THF (5 mL) under an atmosphere of argon, was added trimethylsilylacetylene (260 $\mu \mathrm{L}, 1.85 \mathrm{mmol}, 4$ equiv.), and finally triethylamine $(3 \mathrm{~mL})$. The reaction mixture was refluxed for $48 \mathrm{~h}$, then cooled to $\mathrm{rt}$ and was filtered over a pad of silica gel, washed with EtOAc. After concentration under vacuum, the residue is dissolved in $\mathrm{MeOH}(10 \mathrm{~mL}), \mathrm{K}_{2} \mathrm{CO}_{3}$ was added $(500 \mathrm{mg})$ and the reaction mixture was refluxed for $10 \mathrm{~min}$. After cooling to $\mathrm{rt}$, the reaction mixture was diluted with water $(20 \mathrm{~mL})$, extracted with EtOAc $(3 \times 30 \mathrm{~mL})$, washed with brine $(30 \mathrm{~mL})$, dried over $\mathrm{MgSO}_{4}$, filtered and concentrated. The residue was purified over silica gel $\left(\mathrm{CH}_{2} \mathrm{Cl}_{2}\right.$ : EtOAc, $80: 20)$ to give brownish solid $5 \mathbf{j}(48 \mathrm{mg}, 50 \%) .{ }^{1} \mathrm{H}$ NMR $\left(300 \mathrm{MHz}, \mathrm{CDCl}_{3}\right) \delta \mathrm{ppm}: 9.50$ $(\mathrm{dd}, J=8.2,1.7 \mathrm{~Hz}, 1 \mathrm{H}), 9.11(\mathrm{dd}, J=4.4,1.7 \mathrm{~Hz}, 1 \mathrm{H}), 9.04(\mathrm{~s}, 1 \mathrm{H}), 8.32(\mathrm{~d}, J=9.4 \mathrm{~Hz}$, 
$1 \mathrm{H}), 8.20(\mathrm{~d}, J=9.4 \mathrm{~Hz}, 1 \mathrm{H}), 7.70(\mathrm{dd}, J=8.3,4.3 \mathrm{~Hz}, 1 \mathrm{H}), 3.50(\mathrm{~s}, 1 \mathrm{H}) .{ }^{13} \mathrm{C} \mathrm{NMR}(75$ $\left.\mathrm{MHz}, \mathrm{CDCl}_{3}\right) \delta \mathrm{ppm}: 152.3,149.3,147.7,140.8,140.2,137.4,133.9,133.0,130.1,125.9$ 122.6, 81.6, 81.0. HRMS (ESI), calcd m/z for $[\mathrm{M}+\mathrm{H}]^{+} \mathrm{C}_{13} \mathrm{H}_{8} \mathrm{~N}_{3}: 206.0718$, found: 276.0715.

\section{BIOLOGICAL ASSAYS}

Ethic statement. Animals were housed, handled, and cared for in strict accordance with the recommendations in the Guide for the Care and Use of Laboratory Animals of the National Institutes of Health (NIH Publication no. 85-23, revised 1996) and with the European Union Council Directives (2010/63/EU). The protocol was approved by the Committee on the Ethics of Animal Experiments Charles Darwin n ${ }^{\circ} 5$ (reference number $\mathrm{N}^{\circ}$ 5012099-A). Animals were manipulated according to protocols that have been validated by the scientific community and all efforts were made to minimize suffering. Animals were housed and maintained at a constant temperature $\left(22 \pm 1{ }^{\circ} \mathrm{C}\right)$ and in a humidity-controlled $(55 \pm 20 \%)$ environment. A 12 $\mathrm{h} / 12 \mathrm{~h}$ light-dark cycle was kept constant, with lights turned on at 08:00 a.m. During the acclimatization period ( 3 days) and throughout all the study, the animals had free access to food and water.

Midbrain cultures. At gestational day 15.5, embryos were collected from the uterine horns of Sprague-Dawley female rats (Janvier LABS, Le Genest St. Isle, France), which had been previously deeply anesthetized with pentobarbital and sacrificed by cervical dislocation. The ventral mesencephalon was dissected out and cultures were prepared using N5 medium and 1 $\mathrm{mg} / \mathrm{mL}$ polyethylenimine as a coating, as previously described. ${ }^{13,18}$ Under these conditions, the loss of DA neurons is spontaneous and progressive as a function of time. ${ }^{16,17}$

Treatments of the cultures. Test treatments were applied after culture plating and then daily after the first 3 DIV and until completion of the cultures. Treatments were renewed by 
exchanging $70 \%$ of the culture medium. Note that vehicles used to solubilize test compounds had no impact on DA cell survival.

Immunolabelling of $\mathbf{T H}^{+}$neurons in culture. After fixation with a $4 \%$ formaldehyde solution in Dulbecco's phosphate buffered saline medium (PBS) for 12 min and two rapid washes with PBS, the cultures were processed for TH immunodetection. Briefly, the cultures were incubated overnight at $4{ }^{\circ} \mathrm{C}$ with a mouse anti-TH monoclonal antibody $(1 / 5000$ in PBS, Euromedex, Souffelweyersheim, France). Subsequent incubations were performed at rt, with a secondary anti-mouse IgG Alexa Fluor 488 (1/500 in PBS, Life Technologies, Paisley, UK). $\mathrm{TH}^{+}$cells were uniquely DA neurons in our culture conditions ${ }^{28}$ and they represented $\sim 2-3 \%$ of the total number of neurons present in these cultures, at the time of plating. ${ }^{26}$

In the phase of screening, image acquisition was performed with the HCI software (Hamamatsu Corp., Bridgewater, NJ) using an inverted fluorescent microscope (TE-300, Nikon, Tokyo, Japan) coupled to an ORCA-ER digital camera (Hamamatsu, Japan). DA cell survival was performed by visual counting of $\mathrm{TH}^{+}$cells at a $200 \mathrm{x}$ magnification using a $20 \mathrm{x}$ objective matched with a $10 \mathrm{x}$ ocular. More precisely, the number of $\mathrm{TH}^{+}$neurons was estimated after counting all visual fields distributed along the $\mathrm{X}$-and $\mathrm{Y}$-axes of each culture well. For post-screening experiments, $\mathrm{TH}^{+}$cell counting was performed with an Arrayscan XTi automated fluorescence microscope (ThermoScientific, Courtaboeuf, France) equipped with the HCStudio software for image acquisition and quantification (Thermoscientific). In this case, data analysis was performed over $60 \%$ of the whole surface area of each culture well.

Quantification of glial cell proliferation. Thymidine-[methyl- $\left.{ }^{3} \mathrm{H}\right]$, a marker of DNA synthesis, was used to quantify glial cell proliferation as described previously. ${ }^{20,25}$ Briefly, midbrain cultures maintained up to $7 \mathrm{DIV}$ in the presence of test treatments were exposed to 
$1 \mu \mathrm{Ci}$ of thymidine-[methyl-3H] (70-90Ci/mmol; Perkin Elmer, Waltham, MA, USA) for $2 \mathrm{~h}$ at $37^{\circ} \mathrm{C}$, in serum-free $\mathrm{N} 5$ medium supplemented with $5 \mathrm{mM}$ glucose. After two rapid washes, the cells were allowed to recover for an additional $2 \mathrm{~h}$ in the same culture medium for eliminating the fraction of radioactivity not incorporated into DNA. After a last wash with PBS, the cells were scraped off culture wells in distilled water and samples assessed by liquid scintillation spectrometry.

Subchronic MPTP mouse model of PD. C57BL/6 male mice (Janvier labs, Le Genest-SaintIsle, France, 22-28 g) were divided into 4 groups ( $n=12 /$ group) for testing the effects of compound 5m in vivo. One group received MPTP hydrochloride $(20 \mathrm{mg} / \mathrm{kg}$, i.p.; once daily) injected for 5 consecutive days ${ }^{29}$, a treatment, which was followed by a washout period of 3 days. Two groups received MPTP together with $\mathbf{5 m}$ hydrochloride, administrated per os in $1 \%$ carboxymethylcellulose and $0.5 \%$ of tween $80(2 \times 25$ or $2 \times 50 \mathrm{mg} / \mathrm{kg} / \mathrm{day} ; 10 \mathrm{~mL} / \mathrm{kg})$, the administration starting 3 days before initiation of MPTP treatment and continuing until sacrifice time. The control group received vehicles used for MPTP and $\mathbf{5 m}$ administration and the MPTP group, the vehicle used for $\mathbf{5 m}$ treatment, only. Six hours after the last administration of $\mathbf{5 m}$ or vehicle, all mice were sacrificed by cervical dislocation. The striatums were dissected out, weighted and snap frozen for the measurement of DA and its metabolites. Tissues samples were stored at $-80^{\circ} \mathrm{C}$ and used for HPLC analysis of DA and its metabolites. The caudal part of the brain (containing the SN) was placed in $4 \%$ formaldehyde (in 0.1 M PBS, $\mathrm{pH} 7.4$ ) for 5 days and then, transferred to $20 \%$ sucrose (20\% in $0.1 \mathrm{M}$ PBS) for cryoprotection. Tissues were stored at $-80{ }^{\circ} \mathrm{C}$ until processing for $\mathrm{TH}^{+}$ immunohistochemistry.

HPLC measurement of striatal DA and its metabolites. The striatums from the left hemispheres were homogenized using a Bandelin UW70 ultrasonic probe and 10 volumes $(\mathrm{w} / \mathrm{v})$ of $0.1 \mathrm{~N}$ perchloric acid aqueous solution. Homogenates were then centrifuged at 
$15,000 \mathrm{rpm}$ for $7 \mathrm{~min}$ at $0{ }^{\circ} \mathrm{C}$ before $10 \mu \mathrm{L}$ of supernatant (or calibration standard) was injected into an HPLC with an electrochemical detection system for the assessment of DA, DOPAC and HVA. The system consisted of a MD $150 \times 3.2 \mathrm{~mm} 3 \mu \mathrm{m}$ C18 column (ESA), a dual electrode 5014B micro-dialysis cell (ESA) with the electrode potentials set at $-150 \mathrm{mV}$ and $+375 \mathrm{mV}$. DA and its metabolites were detected at the second electrode, combined with a CoulArray detector (ESA). A 5020 guard cell (ESA) with a potential of $+350 \mathrm{mV}$ was placed before the auto-sampler. The mobile phase contained $90 \mathrm{mM}$ sodium dihydrogen phosphate, $50 \mathrm{mM}$ citric acid, $1.7 \mathrm{mM}$ 1-octane sulphonic acid, $50 \mu \mathrm{M}$ EDTA, 10\% acetonitrile, $\mathrm{pH} 3.0$ at a flow rate of $0.5 \mathrm{~mL} / \mathrm{min}$. The calibration standards contained DA (Sigma-Aldrich, Saint Quentin Fallavier, France), DOPAC (Sigma-Aldrich, Saint Quentin Fallavier, France) or HVA (Sigma-Aldrich, Saint Quentin Fallavier, France). A calibration curve was created from a range of standards $(24.4-1562.5 \mathrm{ng} / \mathrm{mL})$.

HPLC measurement of $\mathbf{5 m}$ in plasma and brain. $\mathbf{5 m}$ was injected i.v. at $1 \mathrm{mg} / \mathrm{kg}$ to CD1 mice (Charles River) and the levels of this compound were determined in plasma/brain using UHPLC with a triple quadrupole detection system (Shimadzu LC-MS 8030). Briefly, plasma aliquots $(400 \mu \mathrm{L})$ were poured in acetonitrile $(1 \mathrm{~mL})$, stirred for $3 \mathrm{~min}$ and sonicated for 3 more min (ultrasonic probe) prior to centrifugation at $4{ }^{\circ} \mathrm{C}$ or $5 \mathrm{~min}$, at $15,000 \mathrm{rpm}$. After removal from the skull, brains were homogenized in a saline solution $(0.9 \%$ aqueous solution, $400 \mu \mathrm{L}$ ) before being processed as plasma samples. The supernatants from brain or plasma samples or the calibration standards containing $\mathbf{5 m}$, at concentrations comprised between 0.05 and $5 \mathrm{nM}$, were then injected into the UHPLC-MS/MS system for quantification.

Detection of SN $\mathbf{T H}^{+}$neurons in tissue sections. Twenty micrometer coronal sections of the mesencephalon obtained with a freezing microtome were collected in 10 regularly spaced series. All sections were stored in PBS $/ 0.4 \%$ sodium azide solution, at $4{ }^{\circ} \mathrm{C}$ until use. They 
were rinsed in PBS $0.1 \mathrm{M}$, treated with $0.3 \% \mathrm{H}_{2} \mathrm{O}_{2} / \mathrm{PBS}$ for 30 min to neutralize endogenous peroxidase activity, and incubated with 5\% goat serum (Sigma-Aldrich, Saint Quentin Fallavier, France) in PBS $/ 0.15 \%$ Triton X-100 for $1 \mathrm{~h}$. Sections were then incubated with a mouse anti-TH (1/500 in PBS; US Biologicals, Salem, USA) antibody for 24 hours. After washing with PBS and incubating for $1 \mathrm{~h}$ with a biotinylated anti-mouse antibody diluted $1 / 250$ in PBS (Vector Laboratories, Burlingame, USA), the staining was revealed with a streptavidin-biotin horse radish peroxidase preformed complex (Vector Laboratories, Burlingame, USA) and DAB (Sigma-Aldrich, Saint Quentin Fallavier, France) as the chromogen.

Quantification of SN DA neurons in tissue sections. Quantification of DA cell loss was done stereologically on regularly spaced DAB-stained sections covering the whole mesencephalon from the rostral pole of the SN to the caudal part of the structure, as already reported. ${ }^{30}$ High-resolution bright-field digital images of labelled sections were acquired using a NanoZoomer Digital Scanner (Hamamatsu Photonics France, Massy, France. objective $\times 40$ ) equipped with the NDP software (Hamamatsu Photonics France, Massy, France.). One $\mathrm{SN}$ was delineated at $\times 4$ magnification for each section. $\mathrm{TH}^{+}$cell bodies were subsequently quantified stereologically in magnified images $(\times 20)$ from selected regions using the ImageJ software (W.S. Rasband, ImageJ, US National Institutes of Health, Bethesda, MD). Total cell numbers were assessed by integration along the rostrocaudal extent of the SN. ${ }^{30}$ The quantification was performed by an experimenter blinded to the treatment groups. The total number of $\mathrm{SN} \mathrm{TH}^{+}$neurons in one hemisphere varied from 4850 to 5535 in saline-treated mice.

Assessment of MAO-B inhibition. The potential of $\mathbf{5 m}$ to inhibit MAO-B activity, was assessed using a modification of a protocol published by Scorza et al. ${ }^{31}$ Briefly, $\mathbf{5 m}$ or the reference MAO-B inhibitor selegiline, were added to an ammonium acetate buffer solution 
( $\mathrm{pH}$ 7.4) containing a crude rat brain mitochondrial extract, the MAO-B specific substrate 4dimethylaminophenethylamine, aldehyde dehydrogenase and the pyridine nucleotide cofactor $\beta$-NAD. After 30 min of incubation at $37^{\circ} \mathrm{C}, \mathrm{HClO}_{4}$ was added to stop the reaction and the supernatant recovered by centrifugation for the dosage of the reaction product 4dimethylaminophenylacetic acid, using HPLC-HRMS.

Data analysis. All statistical analyses were performed using SigmaPlot 11.0. For in vitro experiments, experimental values expressed as mean \pm S.E.M were derived from at least triplicates of 3 independent experiments. For in vivo experiments, the number of samples in each group of treatment is given in the text or the figure caption. Multiple comparisons against a single reference group were made by one-way analysis of variance (ANOVA) followed by the Dunnett's post-hoc test. When all pairwise comparisons were required, we used the Student-Newman-Keuls post-hoc test. A p value of less than 0.05 was considered significant.

\section{ASSOCIATED CONTENTS}

\section{Supporting Information}

The Supporting Information is available free of charge on the ACS Publications website at DOI:

Copy of ${ }^{1} \mathrm{H}$ and ${ }^{13} \mathrm{C}$ NMR spectra (PDF)

\section{AUTHOR INFORMATION}

\section{Corresponding Authors}

*Phone: +33 146835598. E-mail: bruno.figadere@u-psud.fr; Phone:+33 157274534. E-mail: patrick-pierre.michel@upmc.fr.

\section{Author Contributions}


G.L.D. synthesized and characterized compounds and performed biological tests. L.F. synthesized and characterized compounds, and wrote the paper. J.S.-D. performed biological tests. B.S.-M. synthesized compound $\mathbf{5 m}$ in bulk quantity. R.R.-V. co-supervised the biological assays. P.P.M. supervised biological assays and wrote the manuscript. B.F. designed the study, supervised the project and wrote the manuscript.

\section{Funding}

The research leading to these results was supported by program Investissements d'Avenir ANR-10-IAIHU-06 and ANR-11-INBS-0011-NeurATRIS: Translational Research Infrastructure for Biotherapies in Neurosciences, by Institut Carnot and ANR-10-labx-33.

\section{Notes}

The authors declare no competing financial interest.

\section{ACKNOWLEDGMENTS}

Motac (Manchester, UK) performed the in vivo treatments protocols with MPTP and the measurements of DA and its metabolites whereas TechMedIll (Strasbourg, France) carried out the pharmacokinetics experiments. This work benefited from equipment and services of the Celis and Histomics core facilities, at ICM. We thank Alexis Genin, director of research applications at ICM for his help in the valorisation process of our compounds. We also thank Karine Leblanc (Univ. Paris-Sud, BioCIS) who performed analyses of purity and HRMS and Dr. A. Harfouche (Univ. Paris-Sud, BioCIS) for MAO-B experiments. We are grateful to L. Acuña (ICM, Paris) for performing some of the post-screening experiments in vitro and to Prof. T. Morton (UCR, Riverside, USA) for fruitful discussions and proof reading our manuscript.

\section{REFERENCES}

(1) Michel, P.P.; Hirsch, E.C.; Hunot, S. Understanding Dopaminergic Cell Death Pathways in Parkinson Disease. Neuron 2016, 90, 675-91. 
(2) Kincses, Z. T.; Vecsei, L. Pharmacological Therapy in Parkinson's Disease: Focus on Neuroprotection. CNS Neurosci. Ther. 2011, 17, 345-367.

(3) Perry, V.H. Innate inflammation in Parkinson's disease. Cold Spring Harb. Perspect. Med. 2012, 2(9), a009373.

(4) Michel, P.P.; Alvarez-Fischer, D.; Guerreiro, S.; Hild, A.; Hartmann, A.; Hirsch, E.C. Role of activity-dependent mechanisms in the control of dopaminergic neuron survival. $J$. Neurochem. 2007, 101, 289-297.

(5) Connolly, B.S.; Lang, A.E. Pharmacological treatment of Parkinson disease: a review. JAMA 2014, 311, 1670-1683.

(6) Athauda, D.; Foltynie, T. The ongoing pursuit of neuroprotective therapies in Parkinson disease. Nat. Rev. Neurol. 2015, 11, 25-40.

(7) Stocchi, F.; Warren Olanow, C. Obstacles to the development of a neuroprotective therapy for Parkinson's disease. Mov. Disord. 2013, 28, 3-7.

(8) Zhang, H.; Tong, R.; Bai, L.; Shi, J.; Ouyang, L. Emerging targets and new small molecule therapies in Parkinson's disease treatment. Bioorg. Med. Chem. 2016, 24, 14191430.

(9) Schmidt, F.; Champy, P.; Séon-Méniel, B.; Franck, X.; Raisman-Vozari, R.; Figadère, B. Chemicals possessing a neurotrophin-like activity on dopaminergic neurons in primary culture. PLoS ONE 2009, 4, 6215.

(10) Schmidt, F. ; Le Douaron, G. ; Champy, P. ; Amar, M. ; Séon-Méniel, B. ; RaismanVozari, R. ; Figadère, B. Tryptamine-derived alkaloids from Annonaceae exerting neurotrophin-like properties on primary dopaminergic neurons. Bioorg. Med. Chem. 2010, 18, 5103-5113. 
(11) Mayo, J.C.; Sainz, R.M.; Tan, D.X.; Antolín, I.; Rodríguez, C.; Reiter, R.J. Melatonin and Parkinson's disease. Endocrine 2005, 27, 169-178.

(12) Cao, D. ; Xue, R. ; Xu, J. ; Liu, Z. Effects of docosahexaenoic acid on the survival and neurite outgrowth of rat cortical neurons in primary cultures. J. Nutr. Biochem. 2005, 16, 538546.

(13) Le Douaron, G. ; Schmidt, F. ; Amar, M. ; Kadar, H. ; Debortoli, L. ; Latini, A. ; SéonMéniel, B. ; Ferrié, L. ; Michel, P. P. ; Touboul, D. ; Brunelle, A. ; Raisman-Vozari, R. ; Figadère, B. Neuroprotective effects of a brain permeant 6-aminoquinoxaline derivative in cell culture conditions that model the loss of dopaminergic neurons in Parkinson disease. Eur. J. Med. Chem. 2015, 89, 467-479.

(14) Le Douaron, G. ; Ferrié, L. ; Sepulveda-Diaz, J.E. ; Amar, M. ; Harfouche, A. ; SéonMéniel, B. ; Raisman-Vozari, R.; Michel, P. P.; Figadère, B. New 6-aminoquinoxaline derivatives with neuroprotective effects on dopaminergic neurons in cellular and animal Parkinson disease models. J. Med. Chem. 2016, 59, 6169-86.

(15) Vallerotto, S.; Le Douaron, G. ; Bernardat, G.; Ferrié, L. ; Figadère, B. 6-Endo-digcycloisomerisation of $N$-propargylaminoquinoxalines: a new route to $1,4,8$ triazaphenanthrenes. Synthesis, 2016, 48, 3232-3240.

(16) Rousseau, E.; Michel, P. P.; Hirsch, E. C. The iron-binding protein lactoferrin protects vulnerable dopamine neurons from degeneration by preserving mitochondrial calcium homeostasis. Mol. Pharmacol. 2013, 84, 888-898.

(17) Toulorge, D.; Guerreiro, S.; Hild, A.; Maskos, U.; Hirsch, E. C.; Michel, P.P. Neuroprotection of midbrain dopamine neurons by nicotine is gated by cytoplasmic $\mathrm{Ca}_{2}+$. FASEB J. 2011, 25, 2563-2573. 
(18) Michel, P.P.; Agid, Y. Chronic activation of the cyclic AMP signaling pathway promotes development and long-term survival of mesencephalic dopaminergic neurons. $J$. Neurochem. 1996, 67, 1633-1642.

(19) Michel, P. P.; Ruberg, M.; Agid, Y. Rescue of mesencephalic dopamine neurons by anticancer drug cytosine arabinoside. J. Neurochem. 1997, 69, 1499-1507.

(20) Mourlevat, S.; Troadec, J. D.; Ruberg, M.; Michel, P. P. Prevention of dopaminergic neuronal death by cyclic AMP in mixed neuronal/Glial mesencephalic cultures requires the repression of presumptive astrocytes. Mol. Pharmacol. 2003, 64, 578-586.

(21) Bové, J.; Prou, D.; Perier, C.; Przedborski, S. Toxin-induced models of Parkinson's disease. NeuroRx 2005, 2, 484-494.

(22) Smeyne, R.J.; Jackson-Lewis, V. The MPTP model of Parkinson's disease. Mol. Brain Res. 2005, 134, 57-66.

(23) Kuroiwa, H.; Yokoyama, H.; Kimoto, H.; Kato, H.; Araki, T. Biochemical alterations of the striatum in an MPTP-treated mouse model of Parkinson's disease. Metab. Brain Dis. 2010, 25, 177-183.

(24) Dehmer, T.; Heneka, M.T.; Sastre, M.; Dichgans, J.; Schulz, J.B. Protection by pioglitazone in the MPTP model of Parkinson's disease correlates with $\operatorname{IkB} \alpha$ induction and block of NFKB and iNOS activation. J. Neurochem. 2004, 88, 494-501.

(25) Toulorge, D.; Guerreiro, S.; Hirsch, E.C.; Michel, P.P. KATP channel blockade protects midbrain dopamine neurons by repressing a glia-to-neuron signaling cascade that ultimately disrupts mitochondrial calcium homeostasis, J. Neurochem. 2010, 114, 553-564. 
(26) Guerreiro, S.; Toulorge, D.; Hirsch, E.; Marien, M.; Sokoloff, P.; Michel, P.P. Paraxanthine, the primary metabolite of caffeine, provides protection against dopaminergic cell death via stimulation of ryanodine receptor channels. Mol. Pharmacol. 2008, 74, 980989.

(27) Lassus B, Magnifico S, Pignon S, Belenguer P, Miquel MC, Peyrin JM. Alterations of mitochondrial dynamics allow retrograde propagation of locally initiated axonal insults. Sci Rep. 2016, 6, 32777.

(28) Traver, S.; Marien, M.; Martin, E.; Hirsch, E.C.; Michel, P.P. The phenotypic differentiation of locus coeruleus noradrenergic neurons mediated by brain derived neurotrophic factor is enhanced by corticotropin releasing factor through the activation of a cAMP-dependent signaling pathway. Mol. Pharmacol. 2006, 70, 30-40.

(29) Petroske, E., Meredith, G.E., Callen, S., Totterdell, S., Lau, Y.S. Mouse model of Parkinsonism: a comparison between subacute MPTP and chronic MPTP/probenecid treatment. Neuroscience. 2001, 106, 589-601.

(30) Höglinger, G.U., Féger, J., Prigent, A., Michel, P.P., Parain, K., Champy, P., Ruberg, M, Oertel, W.H., Hirsch, E.C. Chronic systemic complex I inhibition induces a hypokinetic multisystem degeneration in rats. $J$ Neurochem. 2003, 84, 491-502.

(31) Scorza, M.C.; Carrau, C.; Silveira, R.; Zapata-Torres, G.; Cassels, B.K.; Reyes-Parada, M. Monoamine oxidase inhibitory properties of some methoxylated and alkylthioamphetamine derivatives: structure-activity relationships. Biochem. Pharmacol. 1997, 54, 1361-9. 
